RODRIGO AUGUSTO SILVA VILA NOVA

\title{
AS TUTELAS DE URGÊNCIA ANTECIPADAS (INCIDENTAL E ANTECEDENTE) NA LEI 9.099/95
}

TRABALHO DE CONCLUSÃO DE CURSO

DEPARTAMENTO DE DIREITO

PROGRAMA DE PÓS-GRADUAÇÃO

Direito Processual Civil - XVI Turma

RIO DE JANEIRO

JULHO/2017 


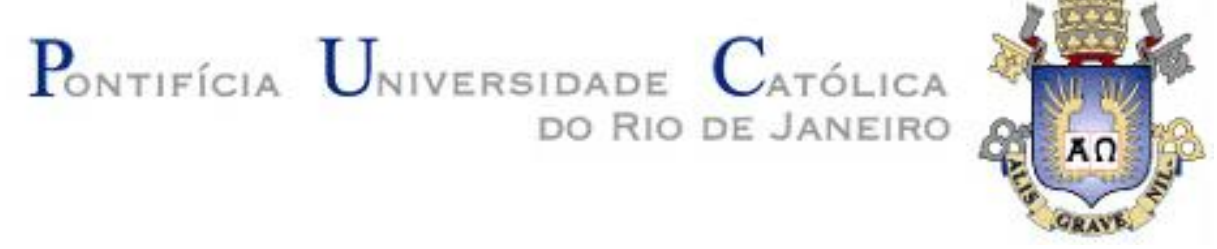

Rodrigo Augusto Silva Vila Nova

\section{AS TUTELAS DE URGÊNCIA ANTECIPADAS (INCIDENTAL E ANTECEDENTE) NA LEI 9.099/95}

Monografia de Conclusão de Curso apresentada ao Programa de PósGraduação em Direito da PUC-Rio como requisito parcial do Curso de Pós-Graduação Lato Sensu em Direito Processual Civil, para obtenção do título de especialista em processo civil.

Orientador: Leonardo Teixeira

Rio de Janeiro

2017

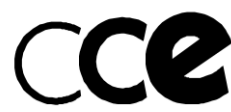




\section{DEDICATÓRIA}

Dedico este trabalho de conclusão de curso a minha mulher, Koca Machado, que foi verdadeiro porto seguro perante todas as dificuldades e, também, pelo seu amor. 


\section{AGRADECIMENTOS}

Agradeço a todos os professores, funcionários da PUC-Rio e amigos que fiz no Curso de Especialização em Processo Civil, pelos sábados maravilhosos de muito aprendizado e conhecimento.

Parabéns pela didática, pelo corpo docente, pela organização, pela estrutura oferecida e, principalmente, pelos ensinamentos que, certamente, irão me auxiliar durante a minha carreira jurídica. Muito obrigado! 


\section{RESUMO}

Advogado. Bacharel em Direito pela Universidade Estácio de Sá do Rio de Janeiro - UNESA Rio.

O presente artigo tem como escopo analisar a aplicação da tutela de urgência antecipada (requerida em caráter incidental ou antecedente) no âmbito do procedimento dos Juizados Especiais Cíveis Estaduais. Abordando a evolução conceitual da tutela de urgência e seus fundamentos constitucionais, bem como as inovações trazidas pelo novo CPC, cotejando-as com a Lei dos Juizados Especiais, objetivando, assim, verificar a compatibilidade do instituto com o rito especial da Lei 9.099/95.

\section{Palavras chave}

Direito Processual Civil - Antecipação de Tutela - Juizados Especiais Cíveis. 


\section{SUMÁRIO}

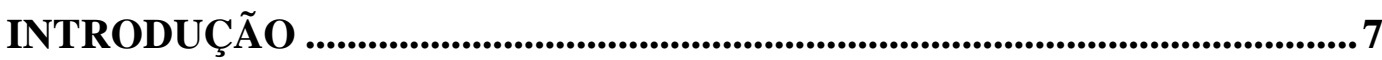

CAPÍTULO 1 - EVOLUÇÃO CONCEITUAL E NATUREZA JURÍDICA

DA TUTELA DE URGÊNCIA ANTECIPADA (SATISFATIVA) ....................8

1.1. O Processo e o Tempo ……………………………………………….... 8

1.2. Evolução Conceitual e Natureza jurídica da Tutela de Urgência Antecipada

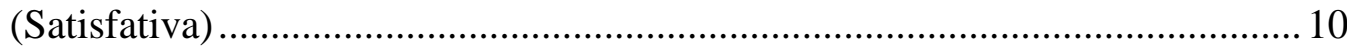

1.3. Fundamentos Constitucionais da Tutela de Urgência Antecipada ............. 14

CAPÍTULO 2 - NOVO CPC E AS TUTELAS DE URGÊNCIA

ANTECIPADAS (SATISFATIVAS); INCIDENTAIS E ANTECEDENTES19

2.1. A Tutela de Urgência Antecipada (Satisfativa) no novo CPC.................. 19

2.2. O procedimento e a estabilização dos efeitos da tutela de urgência antecipada requerida em caráter antecedente ................................................... 24

CAPÍTULO 3 - A LEI 9.099/95 E A APLICABILIDADE DAS TUTELAS DE URGÊNCIA ANTECIPADAS: INCOMPATIBILIDADE?............................. 31

3.1. Os Juizados Especiais cíveis (Lei 9.099/95): Objetivos, Conceito e Princípios Norteadores

3.1.1. As tutelas de urgência antecipadas no procedimento dos Juizados

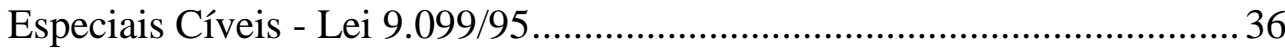

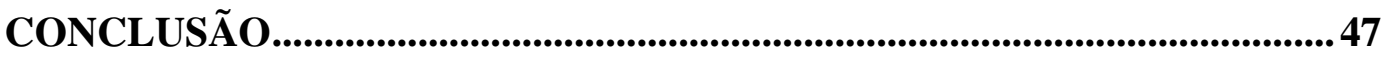

REFERÊNCIAS BIBLIOGRÁFICAS ......................................................48 
Os professores são como grandes mestres, com quem aprendemos muito sobre a vida, dentro ou fora da sala de aula. Muito obrigado, por toda a dedicação e paciência! 


\section{INTRODUÇÃO}

O tempo na duração do processo tem sido fonte de constante preocupação tanto para os operadores do direito quanto para os jurisdicionados, já que a demora na prestação jurisdicional prejudica sua efetividade e pode levar, em casos extremos, ao perecimento do direito que se pretendia proteger pela via processual.

No entanto, ao mesmo tempo em que o direito processual civil deve perseguir a celeridade e a efetividade, deve também, garantir a segurança jurídica e o devido processo legal, sob pena de se transformar apenas em instrumento de proteção do autor, deixando o réu à mercê de demandas desarrazoadas e decisões precipitadas.

Os meios para se obter essa efetividade processual evoluíram de hipóteses específicas de antecipação de tutela (nas ações possessórias, mandado de segurança, embargos de terceiro, busca e apreensão em alienação fiduciária, etc.) à utilização, ainda que não muito bem vista no meio jurídico, de medidas ditas cautelares, mas com cunho satisfativo e, finalmente, à tutela antecipada introduzida de modo generalizado no ordenamento jurídico brasileiro a partir da edição da Lei nº 8.952/94.

O novo Código de Processo Civil inovou quanto às formas de requerimentos da tutela de urgência antecipada, que, agora, podem ser requeridas em caráter incidental ou antecedente, com procedimentos distintos, sempre no intuito de imprimir maior celeridade e efetividade ao processo.

O presente estudo procurará analisar, em linhas gerais, a evolução conceitual da tutela de urgência (satisfativa) e seus fundamentos constitucionais, bem como o tratamento dado à tutela de urgência antecipada (satisfativa) no novo Código de Processo Civil à luz dos princípios constitucionais da efetividade, do devido processo legal e da segurança jurídica, fazendo um paralelo com a Lei 9.099/99, que instituiu os Juizados Especiais Cíveis, para analisar a eventual compatibilidade de seus procedimentos. 


\section{CAPÍTULO 1 - EVOLUÇÃO CONCEITUAL E NATUREZA JURÍDICA DA TUTELA DE URGÊNCIA ANTECIPADA (SATISFATIVA)}

\subsection{O Processo e o Tempo}

O processo judicial, entendido como a sequência de atos coordenados destinados a certo fim (entrega da prestação jurisdicional) ${ }^{1}$, necessariamente, demanda tempo para o seu regular desenvolvimento.

Diante disso, o fator tempo passa a ter fundamental importância para a definição da viabilidade do modelo processual, podendo ser considerado um dos principais pontos de aferição do grau de eficiência de determinado sistema processual $^{2}$.

Delosmar Mendonça Júnior, sobre o tema, assevera que:

(...) a demora na entrega da prestação jurisdicional pode permitir que a passagem de tempo venha influir negativamente no estado de fato ou de direito, provocando uma modificação do quadro que, quando a tutela jurisdicional vier a ser concretizada, pode tornar inútil o respectivo provimento jurisdicional $(. . .)^{3}$.

A Emenda Constitucional $n^{\circ} 45 / 2004$ inseriu no ordenamento pátrio a garantia fundamental da Celeridade Processual, insculpida no art. $5^{\circ}$, inciso LXXVIII da CRFB/1988, que assegura, a todos, no âmbito judicial e administrativo a razoável duração do processo e os meios que garantam a celeridade de sua tramitação ${ }^{4}$.

O Novo Código de processo civil ratificou o princípio da celeridade no seu art. 4: “As partes têm direito de obter em prazo razoável a solução integral do

\footnotetext{
${ }^{1}$ DIDIER JR., Fredie. Curso de direito processual civil. Parte geral. Processo de conhecimento. $17^{a}$ ed. v. 1. Salvador: Ed. Juspodivm, 2015. p. 31.

${ }^{2}$ MENDONÇA, Delasmar et al.. Tutela Diferenciada. $6^{\mathrm{a}}$ ed. Curitiba: IESDE Brasil S.A., 2011. p. 24.

${ }^{3}$ Ibid., p. 24.

${ }^{4}$ BRASIL. Constituição Federal (1988). Art. $5^{\circ}$. Inciso LXXVIII. A todos, no âmbito judicial e administrativo, são assegurados a razoável duração do processo e os meios que garantam a celeridade de sua tramitação. (Incluído pela Emenda Constitucional $n^{\circ} 45$, de 2004). Disponível em: <http://www.planalto.gov.br/ccivil_03/constituicao/constituicao.htm〉. Acesso em: 05 mai. 2017.
} 
mérito...", bem como no inciso II, do art. 139: “O juiz dirigirá o processo conforme as disposições deste código, incumbindo-lhe (...) II- velar pela razoável duração do processo".

A consagração constitucional do princípio da celeridade não garante, por si só, o direito a um processo rápido, devendo ser compreendido como um direito ao processo sem dilações indevidas, sem uma demora excessiva, devendo demorar o tempo necessário e adequado à solução do caso submetido ao órgão jurisdicional ${ }^{5}$.

Leonardo Ferres salienta, que:

Impensável ficar alheio aos efeitos deletérios do tempo de tramitação dos feitos judiciais, porquanto a demora na obtenção da tutela jurisdicional é, por si só, fonte de dano, sendo certo que quanto mais demorado for o processo maior será o dano dele decorrente ${ }^{6}$.

Analisando a celeridade, como pressuposto de um processo justo, Fernando da Fonseca Gajardoni ${ }^{7}$ aponta que "o escopo primordial do processo é a pacificação social, com a consequente satisfação dos interesses das partes, a qual não é obtida quando prolongado no tempo".

Com efeito, é inegável que os diplomas processuais preocupam-se com o tempo no curso do trâmite processual, razão pela qual trazem diversas inovações que possibilitam o afastamento das injustas e lesivas consequências oriundas da excessiva demora na efetiva prestação jurisdicional.

O novo código de processo civil, nos termos do art. $300^{8}$, estabelece que a tutela jurisdicional poderá ser concedida de forma antecipada, quando houver elementos que evidenciem a probabilidade do direito (fumus boni iuris) e o perigo

\footnotetext{
${ }^{5}$ DIDIER JR., 2015, p. 96.

${ }^{6}$ RIBEIRO, Leonardo Ferres da Silva, Tutela provisória: tutela de urgência e de evidência. $2^{\mathrm{a}}$ ed. rev. In: ALVIM, Teresa Arruda; TALAMINI, Eduardo (Coord.). Coleção Liebman. São Paulo: Editora Revista dos Tribunais, 2016. p. 69.

${ }^{7}$ GAJARDONI, Fernando da Fonseca. Os reflexos do tempo no processo Civil. Uma breve análise da qualidade do processo civil e europeu. Disponível em:

<http://myrtus.uspnet.usp.br/pesqfdrp/portal/professores/fernando/pdf/reflexos.pdf>. Acesso em: 5 mai. 2017.

${ }^{8}$ Lei no 13.105 de 16 de Março de 2015 - Art. 300. A tutela de urgência será concedida quando houver elementos que evidenciem a probabilidade do direito e o perigo de dano ou o risco ao resultado útil do processo.
} 
de dano (periculum in mora), antecipando-se assim, provisoriamente, os efeitos da tutela definitiva em situação de urgência.

A antecipação de tutela, conforme Leonardo Ferrez ${ }^{9}$ deve ser entendida como a possibilidade de precipitação dos efeitos da tutela jurisdicional ou, noutras palavras, o adiantamento de efeitos de um futuro provimento de mérito, permitindo a fruição imediata, pelo autor, daquilo que só teria possibilidade de gozar após um longo percurso processual e de tempo.

A técnica antecipatória, nesse contexto, visa à neutralização dos malefícios causados pela demora na entrega da prestação jurisdicional definitiva. Sobre o tema, Daniel Mitidiero ${ }^{10}$.

Pela antecipação de tutela, viabiliza-se a neutralização dos males oriundos do tempo necessário para a obtenção da tutela jurisdicional final. A técnica antecipatória visa a distribuir de maneira isonômica entre as partes o tempo inerente à duração fisiológica do processo.

\subsection{Evolução Conceitual e Natureza jurídica da Tutela de Urgência Antecipada (Satisfativa)}

Durante muito tempo, a doutrina clássica defendeu que a tutela sumária atrelava-se a tutela cautelar, afirmando que toda a tutela cautelar tinha natureza antecipatória, que toda execução fundada em cognição definitiva seria de segurança e que as liminares tinham natureza cautelar ${ }^{11}$.

Diante disso, para a devida compreensão da evolução conceitual da tutela antecipada satisfativa, faz-se necessário revisitar a teoria da tutela cautelar e sua consequente evolução, chegando, assim, a atual compreensão da antecipação da tutela como técnica direcionada a antecipar de maneira provisória, mediante cognição sumária, a tutela jurisdicional do direito à parte visando à distribuição isonômica do ônus do tempo no processo ${ }^{12}$.

\footnotetext{
${ }^{9}$ RIBEIRO In: ALVIM; TALAMINI, 2016, p. 115.

${ }^{10}$ MITIDIERO, Daniel. Antecipação da tutela: da tutela cautelar à técnica antecipatória. $2^{\mathrm{a}}$ ed. Rev., ampl. e atual. São Paulo: Editora Revista dos Tribunais, 2014. p. 69.

${ }^{11}$ Ibid., p. 19-20.

${ }^{12}$ Ibid., p. 19.
} 
A doutrina alemã, no século XIX, inseriu a tutela cautelar no ordenamento jurídico, concebendo-a como uma forma de execução forçada, um primeiro estágio de uma realização gradual do direito, não reconhecendo autonomia conceitual e extensão maior à tutela cautelar do que aquela consentida à execução forçada ${ }^{13}$.

Posteriormente, com a compreensão da ação como pretensão à tutela jurídica autônoma do direito material, a referida doutrina passou a consentir com a colocação do problema da tutela cautelar no âmbito do direito processual ${ }^{14}$.

Giuseppe Chiovenda desenvolve, então, a teorização da ação cautelar como "azione assicurativa”, conceituando-a como as ações que visam a prover com urgência a manutenção do statu quo, como assegurar a futura satisfação de um futuro direito depois de sua declaração, com as quais se efetiva uma tutela de conservação ${ }^{15}$.

Na visão de Chiovenda, do plano do direito material afasta-se o direito à cautela, separando o próprio direito à segurança, compreendendo o direito da parte à cautela como simples poder de provocação da atividade do Estado $^{16}$.

Daniel Mitidiero observa que:

Chiovenda transformou o direito material à cautela da parte no provimento processual erigido no interesse do Estado - em direito do Estado. A parte tem apenas o poder de agir para a realização de um fim estatal. É o Estado como fim e a pessoa como meio ${ }^{17}$.

A teoria de Chiovenda contribuiu, assim, para o afastamento da função cautelar da tutela executiva, deslocando-a do âmbito de proteção dos direitos para tutela da autoridade estatal ${ }^{18}$.

Avançando sobre o tema, Piero Calamandrei, ao contrário de Chiovenda, afasta a construção teórica da tutelar cautelar a partir do conceito de ação, abordando o tema sob a perspectiva do procedimento, onde a provisoriedade do

\footnotetext{
${ }^{13}$ MITIDIERO, 2014, p. 22.

${ }^{14}$ Ibid., p. 22.

${ }^{15}$ Ibid. p. 24.

${ }^{16}$ Ibid. p. 27.

${ }^{17}$ Ibid. p. 28.

${ }^{18}$ Ibid. p. 29.
} 
provimento, dotado de cognição sumária, era o fator decisivo para caracterização da tutela cautelar ${ }^{19}$.

Na sua concepção, a estrutura provisória do provimento é o que caracteriza o provimento cautelar, e sob o ponto de vista funcional, o provimento cautelar objetiva assegurar que o processo não sofra dano jurídico, ocasionado pelo perigo de tardança, ou de infrutuosidade na entrega definitiva da prestação jurisdicional ${ }^{20}$.

Calamandrei defendia a dependência e acessoriedade do provimento cautelar em relação ao provimento do processo de conhecimento e de execução, servindo como verdadeiro (instrumento do instrumento) para proteção provisória do processo $^{21}$.

Defendia também que, os provimentos cautelares podiam ser tanto assecuratórios quanto satisfativos, não fazendo distinção entre a tutela cautelar e satisfativa, já que, diante do critério da provisoriedade do provimento poder-se-ia cogitar de tutela cautelar ${ }^{22}$.

Nesse passo, conclui Daniel Mitidiero “a tutela cautelar assume a função de neutralizar provisoriamente o perigo de dano capaz de frustrar o resultado útil da jurisdição - vale dizer, o resultado útil do processo principal"23.

O código de processo civil brasileiro de 1973, Código Buzaid, influenciado por Carnelutti, disciplinou o processo cautelar ao lado do processo de conhecimento e do processo cautelar, concebendo-o como tertium genus, um terceiro gênero, que tem por objetivo prevenir a ocorrência de danos, por meio da outorga de uma decisão provisória à parte ${ }^{24}$.

Carnelutti sustentava que a ação cautelar era um direito da parte e que o processo cautelar integrava provisoriamente a lide enquanto não houvesse uma decisão definitiva ${ }^{25}$.

\footnotetext{
${ }^{19}$ MITIDIERO, 2014, p. 29

${ }^{20}$ Ibid., p. 30-31.

${ }^{21}$ Ibid., p. 31.

22 Ibid., p. 32.

${ }^{23}$ Ibid., p. 32.

24 Ibid., p. 35.

${ }^{25}$ Ibid., p. 37.
} 
Daniel Mitidiero tece críticas à teoria proposta por Carnelutti, apontando o seu equívoco ao imaginar que o processo cautelar diferencia-se do processo de conhecimento e do processo de execução pelo seu suposto fim preventivo, bem como salienta que o processo cautelar não visa a outorga de tutela ao processo, mas sim ao próprio direito material.

Com a promulgação do Código Buzaid, parte significativa da doutrina se insurge contra a sistematização ofertada pela doutrina italiana, e adotada pela nossa legislação, caracterizando um passo decisivo no estudo do tema, defendendo que a tutela cautelar não poderia ser confundida com a tutela antecipada, uma vez que a tutela cautelar apenas assegura a possibilidade de fruição eventual e futura do direito acautelado, enquanto a antecipada, desde logo, possibilita a imediata realização do direito ${ }^{26}$.

Conforme lição de Daniel Mitidiero:

Por força da doutrina de Ovídio Batista da Silva, deixa-se de compreender toda tutela sumária como tutela cautelar. No seu pensamento, a tutela sumária passa a ser compreendida como tutela de urgência, gênero no qual se inserem a tutela cautelar, a tutela satisfativa de urgência autônoma e a tutela satisfativa interinal (tutela antecipada). Como é notório foi por conta de suas lições que o direito processual civil positivo brasileiro passou a distinguir tutela cautelar $e$ antecipação de tutela ${ }^{27}$.

Após esse período, com a reforma processual oriunda da Lei $\mathrm{n}^{\circ}$ 8.952/94, as confusões históricas entre as tutelas cautelares e antecipadas satisfativas passaram a ser resolvidas, o que afastou a utilização da ação cautelar, bem como do poder geral de cautela, previsto no art. 798 do $\mathrm{CPC} / 73$, como instrumentos para obtenção de tutelas, notadamente, satisfativas. Reduzindo-se, assim, o espaço das cautelares inominadas e extinguindo-se as chamadas cautelares satisfativas.

Passa-se a compreender a tutela cautelar como uma proteção jurisdicional que visa resguardar o direito à tutela, e não ao processo, e a tutela antecipada (satisfativa) como uma proteção jurisdicional que desde logo realiza um direito, antecipando-se assim os efeitos executivos da tutela definitiva.

\footnotetext{
${ }^{26}$ MITIDIERO, 2014, p. 39-40.

${ }^{27}$ Ibid., p. 41-42.
} 
Na lição de Luiz Guilherme Marinoni, a Tutela Antecipada pode ser definida como:

A tutela do direito que o autor pretende obter ao final do processo, mas que é concedida antecipadamente em virtude de perigo de dano. Em outras palavras, a tutela antecipada é a tutela do direito que, em vista de uma situação de urgência, é prestada com base em probabilidade ou mediante cognição sumária ${ }^{28}$.

Marinoni salienta que não se pode confundir a tutela antecipada com a técnica de antecipação de tutela, ou técnica antecipatória:

A tutela antecipada exige a consideração dos pressupostos de direito material da tutela de direito que se quer antecipar, enquanto a técnica antecipatória nada mais é do que previsão técnico processual que autoriza a antecipação da tutela do direito $^{29}$.

No mesmo caminho, Mitidiero:

A técnica antecipatória é apenas um meio para realização da tutela satisfativa ou da tutela cautelar e essas formas de tutela de tutela jurisdicional devem ser pensadas a partir do direito material - mais propriamente, à luz da teoria da tutela dos direitos ${ }^{30}$.

Quanto à natureza jurídica da tutela antecipada, Reis Friede ${ }^{31}$ define como "inconteste forma de provimento jurisdicional de conhecimento com cognição sumária, relativamente exauriente de cunho satisfativo do direito reclamado, ainda que com matizes de restrita provisoriedade e relativa reversibilidade.

\subsection{Fundamentos Constitucionais da Tutela de Urgência Antecipada}

A Emenda Constitucional $n^{\circ} 45 / 2004$ inseriu no ordenamento pátrio a garantia fundamental da Celeridade Processual, insculpida no art. $5^{\circ}$, inciso

${ }^{28}$ MARINONI, Luiz Guilherme. Tutela de Urgência e Evidência. $1^{\mathrm{a}}$ ed. São Paulo: Editora Revista dos Tribunais, 2017. p. 42.

${ }^{29}$ Ibid., p. 42-43.

${ }^{30}$ MITIDIERO, 2014, p. 50.

${ }^{31}$ FRIEDE, Reis. 1949, Tutela antecipada, tutela específica e tutela cautelar: à luz da denominada Reforma do Código de Processo Civil. $6^{\mathrm{a}}$ ed. Rev., atual. e ampliada de acordo com a Lei $\mathrm{n}^{\circ}$ 10.444, de 7 de maio de 2002. Rio de Janeiro: Forense, 2002. p. 27. 
LXXVIII da CRFB/1988, que assegura, a todos, no âmbito judicial e administrativo a razoável duração do processo e os meios que garantam a celeridade de sua tramitação ${ }^{32}$.

Antes disso, o Pacto de San José da Costa Rica (Convenção Americana de Direitos Humanos), ratificado pelo Brasil, já previa o direito a razoável duração do processo em seus artigos $8^{\circ}, 1^{\circ}$ e $25,1^{\circ}$ :

(...) Artigo $8^{\circ}-$ Garantias judiciais

1. Toda pessoa terá o direito de ser ouvida, com as devidas garantias e dentro de um prazo razoável, por um juiz ou Tribunal competente, independente e imparcial, estabelecido anteriormente por lei, na apuração de qualquer acusação penal formulada contra ela, ou na determinação de seus direitos e obrigações de caráter civil, trabalhista, fiscal ou de qualquer outra natureza. (Grifo nosso)

\section{(...) Artigo 25 - Proteção judicial}

1. Toda pessoa tem direito a um recurso simples e rápido ou a qualquer outro recurso efetivo, perante os juízes ou tribunais competentes, que a proteja contra atos que violem seus direitos fundamentais reconhecidos pela Constituição, pela lei ou pela presente Convenção, mesmo quando tal violação seja cometida por pessoas que estejam atuando no exercício de suas funções oficiais. (...) ${ }^{33}$ (grifo nosso)

Alexandre Freitas Câmara traz importante lição acerca do princípio da celeridade:

Não se pode, pois, considerar que o princípio da tempestividade da tutela jurisdicional sirva de base para construção de processos instantâneos. O que se assegura com esse princípio constitucional é a construção de um sistema processual em que não haja dilações indevidas. Em outros termos, o processo não deve demorar mais que o estritamente necessário para que se possa alcançar os resultados justos visados por força da garantia do devido processo. Deve, porém,

\footnotetext{
${ }^{32}$ BRASIL. Constituição Federal (1988). Art. 5º Inciso LXXVIII. Acesso em: 5 mai. 2017.

${ }^{33}$ BRASIL. Presidência da República. Decreto no 678, de 6 de novembro de 1992. Promulga a Convenção Americana sobre Direitos Humanos (Pacto de São José da Costa Rica), de 22 de novembro de 1969. Disponível em: <http://www.planalto.gov.br/ccivil_03/decreto/d0678.htm>. Acesso em: 7 mai. 2017.
} 
o processo demorar todo o tempo necessário para que tal resultado possa ser alcançado $^{34}$.

Preenchidos os requisitos legais para concessão da tutela de urgência antecipada (satisfativa), a entrega da prestação jurisdicional deve ser garantida a parte requerente com fundamento no princípio da celeridade, efetivando o direito, evitando-se assim eventuais ameaças, lesões, ou o próprio perecimento do direito subjetivo invocado.

A Constituição Federal estabelece também, em seu art. 5, XXXV, da $\mathrm{CRFB} / 1988^{35}$, o direito fundamental da inafastabilidade da jurisdição, garantindo também uma tutela jurisdicional adequada, efetiva e tempestiva ${ }^{36}$.

Cássio Scarpinella Bueno, ao analisar o princípio do acesso a justiça, previsto no art. $5^{\circ}, \mathrm{XXXV}$, da Constituição Federal, defende que o exercício da função jurisdicional deve proteger - por imposição constitucional, adequada, eficaz e rapidamente, as situações de ameaça a direito como situações de lesões a direito $^{37}$.

Nessa perspectiva, a proteção às lesões de direitos, bem como as ameaças a direitos subjetivos inseridas no supracitado artigo constitucional, abrange, inegavelmente, as tutelas de urgência antecipadas (satisfativas).

$\mathrm{O}$ art. $5^{\circ}$, caput, da Constituição Federal Brasileira, consagra o princípio da isonomia, assegurando-se assim, que: “Todos são iguais perante a lei, sem distinção de qualquer natureza, garantindo-se aos brasileiros e aos estrangeiros residentes no País a inviolabilidade do direito à vida, à liberdade, à igualdade, à segurança e à propriedade, nos termos...”

Sobre a influência do princípio constitucional da igualdade no âmbito das tutelas provisórias, Daniel Mitidiero aponta que:

\footnotetext{
${ }^{34}$ CÂMARA, Alexandre Freitas. Lições de Direito Processual Civil. v. 1. $25^{\mathrm{a}}$ ed. São Paulo: Atlas, 2014. p. 68.

35 BRASIL. Constituição Federal (1988). Art. 5 . XXXV: XXXV. A lei não excluirá da apreciação do Poder Judiciário lesão ou ameaça a direito. Disponível em: <http://www.planalto.gov.br/ccivil_03/constituicao/constituicao.htm>. Acesso em: 5 mai. 2017. ${ }^{36}$ WAMBIER, Luiz Rodrigues. TALAMINI, Eduardo. $16^{\mathrm{a}}$ ed. Reformulada e Ampliada de Acordo Com o Novo CPC. São Paulo: Editora Revista dos Tribunais, 2016. p. 860.

${ }^{37}$ BUENO, Cassio Scarpinella. Curso Sistematizado de Direito Processual Civil: Teoria Geral do Direito Processual Civil. v. 1. $8^{\mathrm{a}}$ ed. rev. e atual. São Paulo: Saraiva, 2014. p. 126.
} 
Um processo sem técnica antecipatória está fadado a deixar nas costas do demandante, invariavelmente, todo o peso que o tempo representa na vida do processo. Como a duração de todo e qualquer processo prejudica o demandante que tem razão e beneficia o demandado que não a têm em idêntica medida, a ausência de técnica antecipatória, além de privilegiar determinadas posições sociais em detrimento de outras, representa grave quebra da igualdade de todos perante a ordem jurídica. Demandante e demandado têm de arcar com o peso que o tempo representa no processo de acordo com a maior ou menor probabilidade da posição jurídica por eles defendida em juízo. Fora daí há ofensa à igualdade e, portanto, enfraquecimento de um dos fundamentos em que assentado o Estado Constitucional $^{38}$.

É nesse contexto que se insere a tutela provisória prevista no ordenamento brasileiro para dar efetividade na prestação jurisdicional, afastando as situações de perigo na demora, bem como redistribuindo o ônus do tempo da tramitação processual, quando presente a evidência da razão do demandante, embora o juiz ainda não tenha reunido elementos suficientes para o julgamento definitivo da lide.

Importante ressaltar que, uma das principais características da tutela de urgência antecipada (satisfativa) é o fato de esta ser analisada mediante cognição sumária, ou seja, assentada em análise superficial do objeto litigioso, fazendo com que o julgador decida a partir de juízo de mera probabilidade.

Em virtude da sumariedade da cognição no momento de concessão da tutela de urgência antecipada, ocasião em que o julgador não possui elementos para julgamento definitivo da demanda, pode ocorrer violações ao direito constitucional da ampla defesa e contraditório, bem como do devido processo legal da parte que sofrerá a medida judicial.

Sobre a colisão de direitos fundamentais, quando da aplicação da técnica antecipatória, Leonardo Ferres assevera, que:

Por força do princípio da proporcionalidade o juiz, ante o conflito, deve avaliar os interesses e valores em jogo e dar prevalência àquele que, segundo a ordem jurídica e de acordo com as particularidades do caso concreto, apresentar maior relevo e importância.

\footnotetext{
${ }^{38}$ MITIDIERO, 2014, p. 67.
} 
Nesse contexto, o princípio da proporcionalidade revela-se como um fundamento constitucional autorizador para, em situações excepcionais, tutelar a urgência, sacrificando-se momentaneamente a segurança em prol de outros que, à luz do caso concreto, mereçam preponderância ${ }^{39}$.

Sendo assim, faz-se necessário o sopesamento dos valores jurídicos envolvidos, aplicando-se, assim, a regra da proporcionalidade, ou razoabilidade, no momento da apreciação do provimento judicial que pode (ou não) conceder tutela de urgência a uma das partes envolvidas, evitando-se restrições e, ou, violações a direitos constitucionalmente garantidos ${ }^{40}$. 


\section{CAPÍTULO 2 - NOVO CPC E AS TUTELAS DE URGÊNCIA ANTECIPADAS (SATISFATIVAS); INCIDENTAIS E ANTECEDENTES}

\subsection{A Tutela de Urgência Antecipada (Satisfativa) no novo CPC}

O Novo código de processo civil, Lei nº $13.105 / 15$ reformulou o sistema fundado em cognição sumária, unificando em um mesmo regime geral, "tutela provisória", a tutela antecipada e a tutela cautelar, que se submetiam a disciplinas formalmente distintas no Código de Processo Civil de 1973.

A tutela provisória de urgência, espécie do gênero tutela provisória, subdivide-se em tutela antecipada e cautelar, podendo ser concedidas mediante requerimento em caráter incidental ou antecedente, conforme estabelecido no art. 294, do novo CPC:

Art. 294 A tutela provisória pode fundamentar-se em urgência ou evidência.

Parágrafo único. A tutela provisória de urgência, cautelar ou antecipada, pode ser concedida em caráter antecedente ou incidental ${ }^{41}$.

Conforme capítulo de introdução, o presente artigo tem como objeto a análise da compatibilização das tutelas de urgência antecipadas (incidentais e antecedentes) no âmbito da lei 9.099/95, para tal é necessário fazer um recorte, restringindo a análise tão somente das tutelas de urgência antecipadas (satisfativas).

$\mathrm{O}$ requerimento de tutela antecipada visa à minimização (e até neutralização) das consequências deletérias que a demora na outorga da prestação jurisdicional definitiva pode acarretar ao bem litigioso ${ }^{42}$.

41 BRASIL. Lei $\mathrm{n}^{\circ} 13.105$, de 16 de março de 2015. Código Civil. Disponível em: <http://www.planalto.gov.br/ccivil_03/_ato2015-2018/2015/lei/113105.htm〉. Acesso em: 5 mai. 2017.

${ }^{42}$ RIBEIRO In: ALVIM; TALAMINI, 2016, p. 117. 
O novo CPC estabelece duas formas para o requerimento da tutela de urgência antecipada: em caráter incidental ou antecedente (art. 294, § único, do CPC), levando em conta o momento em que o pedido de tutela é feito.

A tutela antecedente é aquela pleiteada antes da dedução em juízo do pedido principal, já a incidental é aquela pleiteada dentro do processo em que se pede ou já se pediu a tutela definitiva.

Conforme lição de Fredie Didier Jr.:

A tutela provisória incidental é a aquela requerida dentro do processo em que se pede ou já se pediu a tutela definitiva, no intuito de adiantar seus efeitos. É requerimento contemporâneo ou posterior à formulação do pedido de tutela definitiva. A tutela provisória antecedente é aquela que deflagra o processo em que se pretende, no futuro, pedir a tutela definitiva. É requerimento anterior à formulação do pedido de tutela definitiva e tem por objetivo adiantar seus efeitos. Primeiro pede-se a tutela provisória, só depois, pede-se a tutela definitiva ${ }^{43}$.

A tutela de urgência antecipada tem como principais características: a sumariedade da cognição, a provisoriedade e a revogabilidade.

Segundo a doutrina de Fredie Didier Jr., "a sumariedade da cognição ocorre quando a decisão se assenta em análise superficial do objeto litigioso e, por isso, autoriza que o julgador decida a partir de juízo de probabilidade" 44 .

A provisoriedade, na lição de Luiz Rodrigues Wambier ${ }^{45}$, caracteriza-se pela circunstância de o provimento urgente não ter o condão de se tornar juridicamente definitivo: em regra ou a medida urgente é substituída pela tutela final ou, simplesmente perde a eficácia.

Ainda sobre a provisoriedade, Wambier salienta que:

A provisoriedade das medidas aqui examinadas deriva de que elas são destinadas a durar apenas o tempo necessário para tutelar uma situação de emergência ou até

\footnotetext{
${ }^{43}$ DIDIER JR., Fredie; BRAGA, Paula Sarno; OLIVEIRA, Rafael Alexandria de. Curso de Direito Processual Civil: Teoria da Prova, direito probatório, ações probatórias, decisão, precedente, coisa julgada e antecipação dos efeitos da tutela. $10^{\mathrm{a}}$ ed. Salvador: Ed. Juspodivm, 2015. p. 570-571.

${ }^{44}$ Ibid., p. 576.

${ }^{45}$ WAMBIER, Luiz Rodrigues; TALAMINI, Eduardo. Curso Avançado de processo civil. processo comum de conhecimento e tutela provisória. 16 ${ }^{a}$ ed. Editora Revista dos Tribunais, 2016. p. 865 .
} 
que sobrevenha o pronunciamento principal, a que estão instrumentalmente ligadas $^{46}$.

Quanto a sua revogabilidade, tendo em vista que a cognição que aprecia o pedido de tutela é sumária, ou seja, analisa superficialmente o objeto litigioso muitas vezes sem ouvir a parte contrária, baseada em juízo de mera probabilidade, e não de certeza, a tutela pode ser revogada ou modificada mediante fundamentação motivada de forma clara e precisa, conforme estabelecem os artigos. 296, caput e 298, do Novo CPC.

Para requerer a concessão de tutela antecipada, necessário o cumprimento de seus pressupostos autorizadores, previstos no art. 300 e $\S^{\circ}$ do novo CPC: demonstração da probabilidade do direito, do perigo de dano ou o risco ao resultado útil do processo, bem como da reversibilidade da medida.

Nesse passo, para a concessão da tutela de urgência antecipada (satisfativa), é necessária a demonstração da probabilidade do direito (fumus boni iuris), conforme expressa previsão no caput do art. 300, caput do Novo CPC: "A tutela de urgência será concedida quando houver elementos que evidenciem a probabilidade do direito..."

A probabilidade do direito (fumus boni iuris) demanda a demonstração de existência de elementos factíveis nos autos (provas, alegações, etc.), uma "aparência de verdade" suficiente para que a tutela seja antecipada, demonstrando que, provavelmente, a tutela final lhe será concedida ${ }^{47}$.

Na definição de Fredie Didier Jr.:

A probabilidade do direito a ser provisoriamente satisfeito/realizado é a plausibilidade de existência desse mesmo direito. $\mathrm{O}$ bem conhecido fumus boni iuris (ou fumaça do bom direito). Ocasião em que o magistrado deverá avaliar se há "elementos que evidenciem" a probabilidade de ter acontecido o que foi narrado e quais as chances de êxito do demandante ${ }^{48}$.

Importante lição apontada por Luiz Rodrigues Wambier, quanto a probabilidade do direito apontada no art. 300, do novo CPC:

\footnotetext{
${ }^{46}$ WAMBIER; TALAMINI, 2016, p. 875.

${ }^{47}$ MARINONI, 2017, p. 130.

${ }^{48}$ DIDIER JR.; BRAGA; OLIVEIRA, 2015, p. 584.
} 
A rigor, todo julgamento funda-se em plausibilidade. Todo juízo é de verossimilhança, pois uma verdade absoluta é humanamente inatingível. Mas no dispositivo em questão, o termo "probabilidade" está empregado para designar um grau de convicção menor do que o suposto para o julgamento final. A plausibilidade do direito é o juízo possível de se extrair da cognição sumária, não exauriente, superficial. Quem decide em fumus boni iuris não tem necessariamente conhecimento pleno e total dos fatos, e portanto, ainda não precisa ter formado plena convicção quanto a qual seja o direito aplicável ${ }^{49}$.

Com a finalidade de caracterização da urgência, para fins de concessão da tutela de urgência antecipada, o caput do art. 300, do novo CPC, também prevê, expressamente, a necessidade de demonstração do "perigo de dano ou o risco ao resultado útil do processo".

Luiz Guilherme Marinoni ${ }^{50}$ ressalta que o legislador não fala mais em fundado receio de dano irreparável e de difícil reparação (art. 273, CPC/73), aludindo agora ao perigo de dano e o risco ao resultado útil do processo, que, no seu entendimento, servem para evidenciar a possibilidade de gravame no curso do processo que pode colocar risco o direito que se pretende tutelar ou um direito a ele conexo (tutela antecipada).

$\mathrm{O} \S 3^{\circ}$ do art. 300 do novo $\mathrm{CPC}$, repete a regra prevista no código anterior, onde "a tutela de urgência de natureza antecipada não será concedida quando houver perigo de irreversibilidade dos efeitos da decisão”.

Com isso, para requerer tutela antecipada, seja ela incidental ou antecedente, é necessário que o requerente preencha cumulativamente os pressupostos, demonstrando: a probabilidade do direito (fumus boni iuris), o perigo de dano (periculum in mora) e o requisito específico da ausência de perigo de irreversibilidade.

Fredie Didier Jr. ${ }^{51}$ aponta que o dispositivo exige que os efeitos da tutela provisória satisfativa (ou antecipada) sejam reversíveis, sendo possível o retorno ao status quo ante, caso se constate, no curso do processo, que a tutela deferida deve ser alterada ou revogada, sendo verdadeira marca da provisoriedade/precariedade da referida tutela.

\footnotetext{
${ }^{49}$ WAMBIER; TALAMINI, 2016, p. 865.

${ }^{50}$ MARINONI, 2017, p. 127.

${ }^{51}$ DIDIER JR.; BRAGA; OLIVEIRA, 2015, p. 584.
} 
A ideia da reversibilidade gira em torno da possibilidade de reposição, ou seja, do retorno do estado das coisas tal quais existiam antes da providência, podendo também ser considerada a reversibilidade da tutela provisória toda a vez que se configurar a possibilidade de indenização, que seja capaz de efetivamente compensar o dano sofrido ${ }^{52}$.

Tendo em vista que a análise/concessão da tutela de urgência antecipada baseia-se em cognição sumária, ensejando assunção de riscos, o juiz pode condicionar a concessão da medida urgente a uma prestação de caução pelo autor, podendo ser dispensada se a parte economicamente hipossuficiente não puder oferecê-la, conforme preceitua o art. $300, \S 1^{\circ}$, do CPC.

Sobre a caução, prevista no $\S 1^{\circ}$ do art. 300, Marinoni salienta que:

O objetivo dessa regra é garantir o direito à tutela urgente a quem não pode prestar caução. Ou seja, a sua finalidade é evitar que o direito à tutela antecipada somente possa ser exercido por quem tem condições de pagar por ele ${ }^{53}$.

O dispositivo legal possui natureza de contracautela, tendo em vista que, concedida a medida de urgência antecipada, o réu tem assegurada a caução prestada, que lhe protege quanto ao ressarcimento de eventuais danos.

Importante ressaltar a lição de Wambier:

Mas nem toda concessão de medida urgente fica necessariamente condicionada à prestação de caução pelo autor. Caberá ao juiz considerar as circunstâncias concretas: o risco de geração de danos graves com a concessão da medida; os bens jurídicos que serão protegidos pela medida, em cotejo com a possibilidade de o autor prestar caução (sua capacidade econômica) etc. Novamente, trata-se de sopesar os princípios jurídicos envolvidos ${ }^{54}$.

Para concessão da tutela provisória antecipada é necessário, inicialmente, o requerimento da parte interessada conforme estabelece o art. 296, do novo CPC, sendo vedada a concessão ex officio, ressalvadas as hipóteses previstas em lei.

Fredie Didier Jr. ${ }^{55}$ manifesta-se no sentido de que se trata de exigência decorrente da regra da congruência, adotada pelo Código nos arts. $2^{\circ}, 141$, bem como aponta o art. 295 do CPC, que dispõe: “...a tutela será requerida”.

Em sentido oposto, Leonardo Ferres defende que:

\footnotetext{
${ }^{52}$ WAMBIER; TALAMINI, 2016, p. 875-874.

${ }^{53}$ MARINONI, 2017, p. 164.

${ }^{54}$ WAMBIER; TALAMINI, op. cit., p. 885.

${ }^{55}$ DIDIER JR.; BRAGA; OLIVEIRA, 2015, p. 584.
} 
Uma interpretação conectada com "o modelo constitucional do processo", atenta aos princípios da inafastabilidade do controle jurisdicional, da efetividade e da proporcionalidade, não nos permite fechar as portas para a solução da antecipação de tutela de ofício, em situações excepcionais... ${ }^{56}$

De toda sorte, tal argumento não merece acolhida, em razão da responsabilidade objetiva estabelecida no art. 302 do CPC/2015, que não poderia ser estendida à parte beneficiada pela tutela, por ela não requerida.

No mesmo sentido, Wambier:

(...) a responsabilidade objetiva apenas se justifica como um risco assumido por quem requer a tutela provisória. Se a parte optou por pleiteá-la, cabe-lhe responder objetivamente, pouco importando se agiu de boa ou má-fé. Ou seja, a responsabilidade objetiva independe de culpa, mas não dispensa a imputabilidade do resultado danoso ao sujeito (nexo de causalidade). Já quando a medida tiver sido deferida pelo juiz, não houve assunção de risco ${ }^{57}$.

Em observância ao art. 93, inciso IX da Constituição Federal Brasileira, bem como ao art. 293 do novo CPC, a decisão que confirme, conceda ou revogue a tutela provisória deverá estar fundamentada, devendo o juiz de modo claro e preciso motivar o seu convencimento.

O realce dado à necessidade de fundamentação deve-se à relevância e gravidade da decisão sobre tutela provisória. Sua concessão pode gerar efeitos gravosos à parte contra quem ela é deferida - no mais das vezes, sem que se tenha ainda dado a essa parte a oportunidade de integral exercício do contraditório e da ampla defesa. Mas sua denegação, nos casos em que seria necessária, também pode ser causadora de graves danos. Por isso, enfatiza-se a necessidade de fundamentação ${ }^{58}$.

\subsection{O procedimento e a estabilização dos efeitos da tutela de urgência antecipada requerida em caráter antecedente}

Uma das grandes inovações do instituto da tutela de urgência antecipada (satisfativa), trazidas pelo novo CPC, é a forma de requerimento em caráter antecedente, bem como a possibilidade de estabilização dos efeitos da tutela, artigos 303 e 304 do CPC.

$\mathrm{O}$ art. 303 do novo CPC estabelece que "nos casos em que a urgência for contemporânea à propositura da ação, a petição inicial pode limitar-se ao

\footnotetext{
${ }^{56}$ RIBEIRO In: ALVIM; TALAMINI, 2016, p. 157.

${ }^{57}$ WAMBIER; TALAMINI, 2016, p. 880-881.

${ }^{58}$ Ibid., p. 876.
} 
requerimento da tutela antecipada e à indicação do pedido de tutela final, com a exposição da lide, do direito que se busca realizar e o perigo de dano ou do risco ao resultado do processo".

\section{Conforme lição de Fredie Didier Jr.:}

A tutela de urgência satisfativa (antecipada) antecedente é aquela requerida dentro do processo em que se pretende pedir a tutela definitiva, no intuito de adiantar seus efeitos, mas antes da formulação do pedido de tutela final ${ }^{59}$.

Sendo assim, o autor, conforme art. 303 caput do CPC, deve requerer na inicial a tutela antecipada, indicando o pedido de tutela definitiva (que será formulada no prazo previsto para aditamento), expondo a lide e o direito pretendido, com a demonstração e observância dos pressupostos para concessão da medida, indicando também o valor da causa (considerado o pedido de tutela definitiva, artigo $303 \S 4^{\circ}$, do CPC) e, por fim, explicitando o interesse de valer-se do benefício, conforme artigo $305, \S 5^{\circ}$ do CPC.

No caso de decisão que não conceda a tutela, por ausência de elementos que evidenciem o preenchimento dos pressupostos, o autor deverá ser intimado para que promova a emenda da petição inicial no prazo de 5 (cinco) dias, sob pena de indeferimento e de extinção do processo sem resolução do mérito, conforme assegura o $\S 6^{\circ}$ do artigo 303 , do novo CPC.

Concedida a medida antecipatória, conforme o inciso I, do $\S 1^{\circ}$, do art. 303 do CPC, o autor deverá, no prazo de quinze dias, aditar a petição inicial complementando sua argumentação, ocasião em que poderá juntar novos documentos e confirmar o pedido da tutela final. $\mathrm{O}$ aditamento previsto será efetuado nos mesmos autos do pedido de antecipação de tutela $\left(\S 3^{\circ}, 303 \mathrm{CPC}\right)$, sem a incidência de novas custas.

A inobservância deste procedimento resultará na extinção do processo, $\S 2^{\circ}$ do art. 303 do CPC, sem resolução de mérito.

Neste sentido, Marinoni:

No caso em que a tutela é concedida e não se estabiliza (art. 304, CPC), o autor tem o ônus de aditar a petição inicial sob pena de extinção do processo sem

\footnotetext{
${ }^{59}$ DIDIER JR.; BRAGA; OLIVEIRA, 2015, p. 571.
} 
resolução do mérito (art. $303, \S 2^{\circ}, \mathrm{CPC}$ ) e, assim, cessação da eficácia da tutela. Frise-se que o aditamento só é necessário quando a tutela antecipada não se estabiliza, ou seja, quando o réu interpõe agravo de instrumento quando intimado da efetivação da tutela antecipada (...) $\mathrm{O}$ aditamento, como não poderia ser diferente, deve ser feito nos mesmos autos e sem incidência de novas custas processuais (art. 303, $\S 3^{\circ}$ do CPC $)^{60}$.

No caso de concessão da tutela, o juiz deverá citar e intimar o réu para audiência de conciliação ou de mediação na forma do art. 334, ocasião em que, inexistindo autocomposição, o prazo para contestação observará a regra do art. 335, I, do CPC, de 15 dias.

Sobre o prazo de resposta do réu, Fredie Didier 603 E 604, observa que:

(...) o prazo de resposta do réu não poderá começar a ser contado antes de sua ciência inequívoca do aditamento da petição inicial do autor, para que se garanta a ele, réu, o lapso temporal mínimo de quinze dia para resposta à demanda do autor em sua inteireza. Por exemplo, se a causa não admitir autocomposição, não sendo cabível a designação da audiência de conciliação ou mediação (art. 334, § $4^{\circ}$, I, do CPC), o réu será citado de imediato, mas o prazo de resposta só deverá correr da data em que intimado do aditamento da petição inicial ${ }^{61}$.

O réu pode adotar duas medidas em relação à tutela antecipada antecedente concedida: apresentar resposta ou recurso de agravo de instrumento (art. 1.015, I, do CPC) contra a decisão interlocutória, ocasião em que o processo irá se desenvolver regularmente, ou, ficar inerte, ocasião em que a decisão que concedeu a tutela antecipada poderá ser estabilizada e, consequentemente, a extinção do feito (art. 304, $\S 1^{\circ}$ do CPC).

A decisão que concede a tutela provisória é de natureza interlocutória, conforme art. 203, $\S 2^{\circ}$ do CPC, razão pela qual o recurso cabível a ser apresentado será o agravo de instrumento, previsto no art. 1.015, I do CPC.

Conforme previsto no artigo 304 do Código de Processo Civil de 2015: “A tutela antecipada, concedida nos termos do art. 303, torna-se estável se da decisão que a conceder não for interposto o respectivo recurso".

A estabilização da tutela antecipada de urgência em caráter antecedente é uma das inovações trazidas pelo novo código de processo civil. Quando não interposto recurso, a decisão concessiva de tutela antecipada torna-se estável se

\footnotetext{
${ }^{60}$ MARINONI, 2017, p. 229-230. (grifo nosso).

${ }^{61}$ DIDIER JR.; BRAGA; OLIVEIRA, 2015, p. 603-604.
} 
não houver manifestação do réu, e ainda, nos termos do $\S 1^{\circ}$, “o processo será extinto".

\section{Conforme lição de Marinoni:}

O objetivo da regra que prevê a estabilização da tutela antecipada é, por um lado, eliminar a necessidade de discussão de uma questão que, diante da conduta do réu, não gera mais controvérsia, e, de outro, outorgar capacidade de produzir efeitos a uma decisão interna a um processo que resulta extinto sem resolução do mérito $^{62}$.

Assim, concedida a medida antecipatória, o réu deverá manifestar-se, caso contrário, ocorrerá a estabilização da tutela prestada, sem ensejar a imutabilidade da coisa julgada material.

Fredie Didier Jr., em relação à estabilização:

A estabilização da tutela antecipada ocorre quando ela é concedida em caráter antecedente e não é impugnada pelo réu, litisconsorte ou assistente simples (por recurso ou outro meio de impugnação). Se isso ocorrer, o processo será extinto e a decisão antecipatória continuará produzindo efeitos, enquanto não for ajuizada ação autônoma para revisá-la, reforma-la ou invalidá-la. Nesse caso, não há, obviamente, resolução do mérito quanto ao pedido definitivo - até porque a estabilização se dá num momento em que esse pedido sequer foi formulado ${ }^{63}$.

A estabilização prevista consiste na conservação dos efeitos da medida, ou seja, na ausência de manifestação posterior à decisão que concedeu a tutela antecipada, o processo ficará suspenso, entretanto, será mantida a eficácia dos efeitos da referida medida.

Conforme assevera Didier, a estabilização da tutela antecipada "representa uma generalização da técnica monitória para situações de urgência e para a tutela satisfativa na medida em que viabiliza a obtenção de resultados práticos a partir da inércia do réu"64.

No mesmo sentido, Wambier:

A técnica monitória consiste na rápida viabilização de resultados práticos, sem a produção de coisa julgada material, nos casos em que, cumulativamente, (i) há concreta e marcante possibilidade de existência do direito do autor (aferida mediante cognição sumária); e (ii) há inércia do réu. Então transfere-se ao réu o ônus do processo de cognição exauriente.

\footnotetext{
${ }^{62}$ MARINONI, 2017, p. 232.

${ }^{63}$ DIDIER JR.; BRAGA; OLIVEIRA, 2015, p. 604.

${ }^{64}$ Ibid., p. 604.
} 
É o que ocorre na ação monitória. É também precisamente o que se dá na estabilização da tutela antecipada ${ }^{65}$.

Depreendem-se do art. 304, do CPC, quatro requisitos essenciais para a estabilização da decisão que concede a tutela antecipada antecedente: a) requerimento do autor de tutela antecipada (satisfativa) em caráter antecedente; b) ausência de intenção do autor de dar prosseguimento ao processo após a obtenção da tutela; c) existência de decisão que concede a tutela antecipada (satisfativa) em caráter antecedente e d) inércia do réu (ausência de impugnação).

Observa-se, que a inércia do réu fica afastada quando ocorrer a apresentação antecipada de contestação, no lugar da interposição do recurso cabível, impedindo, assim a extinção do processo e, também, consequentemente, a estabilização da tutela.

Conforme aponta Fredie Didier, neste caso:

(...) o juiz terá que dar andamento ao processo para aprofundar sua cognição e decidir se mantém a decisão antecipatória ou não. Não se pode negar ao réu o direito a uma prestação jurisdicional de mérito definitiva ${ }^{66}$.

De fato, em que pese a lei estabelecer especificamente a interposição de recurso, qualquer forma de oposição ao pleito deverá ser capaz de afastar a extinção do processo, bem como a possibilidade de estabilização.

O $\S 2^{\circ}$, do art. 304 do CPC estabelece que "qualquer das partes poderá demandar a outra com o intuito de rever, reformar ou invalidar a tutela antecipada estabilizada".

Marinoni ressalta que:

Como é óbvio, se a tutela do direito é insuficiente ao autor, ele não fica impedido de propor ação para pleitear uma ou outra forma de tutela (v.g. inibitória quando antes pedida remoção do ilícito), outro modo de prestação da tutela (v. g.) paralisação de atividades quando antes requerida instalação de filtro) ou a própria tutela de direito em maior extensão (v. g. ressarcitória na forma específica quando antes pedida ressarcitória pelo equivalente, ou seja, antecipação de soma)... Ora, se a decisão que concede a tutela que se estabiliza não produz coisa julgada, o autor fica livre para pedir outro modo de prestação da tutela ou tutela que vá além da estabilizada ${ }^{67}$.

No mesmo sentido, Fredie Didier:

\footnotetext{
${ }^{65}$ WAMBIER; TALAMINI, 2016, p. 892.

${ }^{66}$ DIDIER JR.; BRAGA; OLIVEIRA, 2015, p. 609.

${ }^{67}$ MARINONI, 2017, p. 240.
} 
O autor, por exemplo, poderá propor ação no simples intuito de confirmar a decisão, agora em cognição exauriente e aptidão para fazer coisa julgada. Isso tem especial relevância naqueles casos em que ele, demandante, poderia ter manifestado interesse no prosseguimento do processo em que fora deferida a tutela provisória antecedente, mas não o fez, de modo que, com a superveniente inércia do réu, houve estabilização da tutela antecipada ${ }^{68}$.

Neste caso, qualquer uma das partes tem legitimidade para propor ação para discutir a tutela estabilizada, no prazo de dois anos contados da ciência da decisão que extinguiu o processo ( $\operatorname{art} .304, \S 5^{\circ}$, do CPC), com o intuito de rever, reformar ou invalidar a tutela estabilizada.

A competência funcional dessa ação será a do juízo que analisou o processo que deu origem à estabilização, conforme estabelece o art. $304, \S 4^{\circ}$, do CPC, "prevento o juízo em que a tutela antecipada foi concedida", podendo a parte requerer o desarquivamento dos autos para a obtenção de elementos capazes de instruir a petição inicial da ação.

A decisão que concede a tutela antecipada antecedente, estabilizada, não fica acobertada pela coisa julgada, conforme estabelece o art. $304, \S 6^{\circ}$, do novo CPC, que manteve a regra tradicional da ausência de coisa julgada em sede de cognição sumária.

Importante destacar que o art. 304, $\S 6^{\circ}$, do novo $\mathrm{CPC}$, assegura que a decisão que concede a tutela não produz coisa julgada, bem como ressalta o prazo de 2 anos para propositura da ação de revisão ( $§ 2^{\circ}$ do art. 303 do CPC), ocasião em que extingue-se o direito de "rever, reformar ou invalidar" a tutela deferida, que se estabilizou.

Neste ponto, Marinoni é brilhante na análise da questão:

Ora, não ter mais o direito de reformar ou invalidar a tutela antecipada não significa não poder mais discutir o direito que foi suposto como provável para se conceder a tutela. Este direito pode ser rediscutido em qualquer processo, desde que não para reformar ou invalidar a tutela antecipada ${ }^{69}$.

E continuando, Marinoni finaliza:

Contudo, como a passagem do prazo de dois anos para o exercício do direito de revisão da tutela estabilizada não faz surgir coisa julgada, a questão jurídica decidida enquanto prejudicial à concessão da tutela não só pode voltar a ser analisada enquanto pedido ou mesmo como questão prejudicial à formulação de

\footnotetext{
${ }^{68}$ DIDIER JR.; BRAGA; OLIVEIRA, 2015, p. 611.
}

${ }^{69}$ MARINONI, op. cit., p. 245. 
pedido em ação de cognição exauriente, como também pode permitir decisão inversa ou contrária sem que se possa falar em violação de coisa julgada ${ }^{70}$.

Ou seja, findo o prazo de dois anos previsto no $\S 5^{\circ}$, do art. 304 do CPC, encerra-se a oportunidade para o ajuizamento de ação que vise "rever, reformar ou invalidar" a tutela estabilizada, todavia, a propositura de uma ação, para se discutir o mesmo direito em cognição exauriente, não fica suprida, por não possuir qualquer vinculação com a primeira.

\footnotetext{
${ }^{70}$ MARINONI, 2017, p. 246.
} 


\section{CAPÍTULO 3 - A LEI 9.099/95 E A APLICABILIDADE DAS TUTELAS DE URGÊNCIA ANTECIPADAS: INCOMPATIBILIDADE?}

\subsection{Os Juizados Especiais cíveis (Lei 9.099/95): Objetivos, Conceito e Princípios Norteadores}

A Lei 9.099/95, que instituiu os Juizados Especiais Cíveis, surgiu no ordenamento jurídico Brasileiro objetivando atender as camadas mais vulneráveis da população, garantindo o acesso à justiça nas causas de menor complexidade e de pequeno valor, visando maior efetividade da Justiça, mediante procedimento simplificado, informal, menos oneroso, célere e tempestivo, diferenciando-se assim, da Justiça Comum ${ }^{71}$.

Ao analisar a sistemática adotada pelo legislador na Lei 9.099/95, extrai-se a ideia de que os Juizados Especiais Cíveis têm como principal objetivo a prestação de tutela jurisdicional de forma simplificada, sem rigor formal e fundada na celeridade.

Na visão do professor Felipe Borring, os Juizados Especiais Cíveis podem ser conceituados como:

(...) o conjunto de órgão judiciais, com assento constitucional e integrante do Sistema dos Juizados Especiais, estruturado para promover a conciliação de determinadas causas e também a conciliação, a arbitragem, o julgamento, a revisão e a execução das causas cíveis de menor complexidade e de pequeno valor, através de princípios e procedimentos específicos, previstos na Lei $n^{\circ}$ $9.099 / 1995^{72}$.

$\mathrm{O}$ art. $2^{\circ}$, da Lei 9.099/95, demonstra a força principiológica na orientação e aplicação da legislação especial:

\footnotetext{
${ }^{71}$ BRASIL. Presidência da República. Lei no 9.099 , de 26 de setembro de 1995. Dispõe sobre os Juizados Especiais Cíveis e Criminais e dá outras providências. Disponível em: <http://www.planalto.gov.br/ccivil_03/leis/L9099.htm〉. Acesso em: 30 jun. 2017.

${ }^{72}$ ROCHA, Felipe Borring. Manual dos Juizados Especiais Cíveis Estaduais: Teoria e Prática. $6^{\mathrm{a}}$ ed. São Paulo: Atlas, 2012. p. 21.
} 
(...) O processo orientar-se-á pelos critérios da oralidade, simplicidade, informalidade, economia processual e celeridade, buscando, sempre que possível, a conciliação ou a transação.

Conforme nos ensina Cassio Scarpinella Bueno, os critérios orientativos destacados devem ser compreendidos como verdadeiros princípios que, como tais devem guiar o intérprete e aplicador do direito ao longo do exame de todo aquele diploma legislativo e, mais amplamente, de todo o microssistema dos Juizados Especiais $^{73}$.

Ao analisar os princípios constantes no supracitado artigo, Felipe Boring Rocha $^{74}$ aponta sua natureza, eminentemente, procedimental, uma vez que voltam-se para disciplinar a integração e o desenvolvimento dos procedimentos previstos na Lei 9.099/95, ressaltando que o tema central dos princípios listados é o ato processual, sua realização, exteriorização e aproveitamento.

Importante frisar, e levar em consideração, que os princípios apontados no artigo $2^{\circ}$, da Lei dos Juizados Especiais Cíveis, não afastam por si só a observância de princípios Constitucionais, como por exemplo, da ampla defesa, contraditório, devido processo legal, dentre outros, devendo aplicá-los de forma cogente, não só por determinação Constitucional, mas também por imposição lógica do ordenamento jurídico ${ }^{75}$.Dentre os princípios elencados no Microssistema dos Juizados Especiais Cíveis, cabe destacar, analisando-os separadamente, os princípios da: simplicidade, informalidade, economia processual, celeridade e oralidade, que definem e diferenciam o procedimento especial do procedimento comum.

O princípio da simplicidade está intimamente ligado à tentativa de desburocratização do procedimento especial, traduzindo a ideia de que o procedimento deve ser simples, direto e claro, em uma série concatenada e enxuta de atos processuais rumo à prolação da sentença ${ }^{76}$.

\footnotetext{
${ }^{73}$ BUENO, Cassio Scarpinella. Curso Sistematizado de Direito Processual Civil - Procedimentos do Código de Processo Civil, Juizados Especiais. $3^{\mathrm{a}}$ ed. $2^{\mathrm{a}}$ tiragem. T. II, 2014. p. 229.

${ }^{74}$ ROCHA, 2012, p. 24.

${ }^{75}$ Ibid., p. 24.

${ }^{76}$ PELEJA JUNIOR, Antonio Veloso; OLIVEIRA, Humberto Santarosa de. O procedimento dos juizados especiais cíveis na perspectiva principiológica do Novo Código de Processo Civil: contraditório e motivação das decisões como alicerces do devido processo legal In: Coleção Repercussões do Novo CPC. v. 7. Editora Juspodium, 2015. p. 70.
} 
Analisando a Legislação Especial, encontra-se a materialização do supracitado princípio em diversos dispositivos, destacando-se os seguintes artigos:

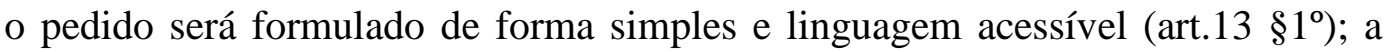
citação pode ser feita por oficial de justiça independentemente de mandado ou carta precatória (art. 18, inciso III), as intimações podem ser feitas por qualquer meio idôneo (art. 19); a sentença pode ser concisa (art. 38), dentre outros.

O princípio da informalidade está ligado à ausência de formas, aquilo que não contém ou apresenta formalidade, ou seja, pressupõe a ausência de rigidez, rigor, na prática dos atos processuais, o que acaba por conectá-lo ao princípio da simplicidade.

Neste passo, orienta que os atos processuais devem ser praticados com o mínimo de formalidade possível, tornando-se simples, econômicos, céleres e efetivos, podendo ser definido como a busca pela limitação das formas do ato para que ele possa ser melhor praticado ${ }^{77}$.

Na definição de Cassio Scarpinella Bueno, a informalidade é:

(...) a ausência de formalismos e, menos que eles, de quaisquer formalidades, que não possam justificar a proteção de algum direito ou interesse mais relevante de qualquer das partes ou das garantias da regularidade e desenvolvimento do processo $^{78}$.

O Princípio da economia processual resume-se a busca pelo máximo rendimento/resultado da lei, conjugado com o mínimo possível de esforço/atos processuais e emprego de energia. Podendo ser definido como a busca por uma maior racionalização das atividades processuais, com o objetivo de obtenção de maior número de resultados com a realização do menor número de atos possível ${ }^{79}$.

O Princípio da Celeridade tem como ideia nuclear a eficiência do processo, que deve ser realizado, observando-se a segurança jurídica, com rapidez e presteza, entregando ao jurisdicionado a tutela definitiva no menor espaço de tempo possível ${ }^{80}$.

\footnotetext{
${ }^{77}$ ROCHA, 2012, p. 29.

${ }^{78}$ BUENO, 2014, p. 230.

${ }^{79}$ ROCHA, op. cit., p. 30.

${ }^{80}$ BUENO, 2014, p. 230.
} 
O princípio da oralidade significa o prevalecimento da palavra oral sobre a escrita, trata-se de um dos princípios mais importantes da Lei 9.099/95, verdadeira norma informadora de outras regras e (sub)princípios, essenciais ao processo nos Juizados Especiais.

Decorrem, assim, do princípio da oralidade, a identidade física do juiz, a imediatidade (dever que o juiz tem de coletar diretamente as provas, em contato com as partes), a concentração dos atos processuais (os atos processuais devem ser concentrados em um único momento ou, pelo menos, em poucos momentos, próximos uns dos outros, para que a palavra oral possa prevalecer), a irrecorribilidade das decisões interlocutórias (as decisões interlocutórias proferidas não precluem, podendo ser impugnadas uma só vez, junto com a sentença) e a publicidade.

A incidência da oralidade no rito especial dos Juizados é marcante, podendo destacar a sua presença na possibilidade de instauração de processo com a apresentação de pedido oral (art. 14), com forma simples e linguagem acessível ( $\S 1^{\circ}$ do art. 14), na contestação do réu que pode ser apresentada de forma oral (em audiência), ou escrita (art. 30), ocasião em que a impugnação do autor deve ser feita oral mente em audiência (art. 31), na inspeção judicial (art. 35, § único), na perícia (art. 35, caput).

Analisados os princípios da lei especial, é necessária a compreensão da finalidade a que se destinam. Nesse caso, importante lição é apresentada por Elpídio Donizetti:

Os princípios norteadores dos juizados especiais servirão como peneira. A normatividade provinda do CPC somente será aplicável se passar por esses filtros, se a aplicação supletiva tornar ainda mais concreto o objetivo que os juizados pretendem alcançar, que é o de atender o maio número de litigantes possível $^{81}$.

No mesmo sentido, Felipe Borring Rocha entende, que:

(...) os princípios arrolados no art. $2^{\circ}$ formam um filtro que, envolvendo o sistema, permitem somente a passagem do que é compatível com seus institutos,

\footnotetext{
${ }^{81}$ DONIZETTI, Elpídio. A corte dos homens pobres e a principiologia do CPC/2015: O que serve ou não aos Juizados Especiais? In: Coleção Repercussões do Novo CPC. v. 7. Editora Juspodium, 2015. p. 88.
} 
dentro de uma lógica de interpretação de valores. A estrutura dos Juizados, portanto, não é simplesmente preenchida pelas demais normas processuais, mas por elas integradas. A regra hermenêutica aplicável, nesse caso, não é apenas a especialidade, mas também a compatibilidade teleológica ${ }^{82}$.

Diante disso, independente de regras que prescrevam a aplicabilidade de outros institutos no procedimento dos Juizados Especiais Cíveis (não previstos na Lei 9.099/95), deve-se verificar a sua compatibilidade analisando a sistemática principiológica adotada pelo legislador, ocasião em que, verificada a incompatibilidade a regra deve ser afastada.

Nesse sentido, importante jurisprudência da Quarta Turma Recursal Cível do Tribunal de Justiça do Estado do Rio de Janeiro:

QUARTA TURMA RECURSAL CÍVEL MANDADO DE SEGURANÇA: 0000079-47.2017.8.19.9000 IMPETRANTE: CASABELLA CARIOCA COOPERATIVA HABITACIONAL IMPETRADO: JUIZ DE DIREITO DO $2^{\circ}$ JUIZADO ESPECIAL CÍVEL DA COMARCA DA CAPITAL/RJ DESCONSIDERAÇÃO DA PERSONALIDADE JURÍDICA. JUIZADO ESPECIAL CÍVEL. FORMAÇÃO DE INCIDENTE EM APARTADO. INCOMPATIBILIDADE COM O PROCEDIMENTO ESTABELECIDO PELA LEI 9.099/95. CONVERSÃO DA PENHORA EM ARRESTO. POSSIBILIDADE. (...) A principiologia dos juizados guarda relação com as fontes materiais - no caso, as razões históricas - que determinaram a sua criação. Dessa forma, ainda que uma regra do Código prescreva que este ou aquele instituto aplica-se aos juizados especiais. Em se verificando que esse instituto vai de encontro a tal conjunto de princípios, a aplicação da regra deve ser afastada." É por isso que qualquer diálogo das fontes deve ser formulado observando os princípios da oralidade, simplicidade, informalidade, não se podendo permitir um monólogo das fontes em detrimento do Sistema estabelecido pela Lei 9.099/95, até porque o devido procedimento legal a que faz referência o art. 98, I da Constituição Federal (oral e sumariíssimo) nada mais é do que um devido procedimento legal simples e simplificado, que atenda à sua finalidade de forma célere e econômica, se possível através da conciliação ou da transação. Por sua vez, é por isso que, nas hipóteses de divergências, de natureza processual, entre o Código de Processo Civil e a Lei 9.099/95, a autonomia dos Juizados Especiais para regular o seu procedimento deve ser preservada, devendo a interpretação ser realizada à luz dos princípios reitores do Sistema dos Juizados Especiais Cíveis 2 . Claro que, com isso, não queremos dizer que os princípios mencionados são os únicos a serem observados: as normas Constitucionais, assim como os princípios da ampla defesa, do devido processo legal, do contraditório, e da fundamentação substancial, dentre outros, são a sustentação do Sistema dos Juizados. Contudo, por força do art. 98, I da Constituição Federal, o devido processo legal nos Juizados Especiais é sumariíssimo e oral, e que, em razão disso, o princípio do contraditório e da ampla defesa encontram restrições sistêmicas significativas se comparadas às possibilidades existentes no modelo processual estabelecido pelo CPC. Por exemplo, no Sistema dos Juizados, o número de testemunhas é limitado

${ }^{82}$ ROCHA, 2012, p. 24. 
a três para cada parte3, já no CPC/2015, o número de testemunhas arroladas pelas partes é de dez, sendo três para a prova de cada fato4. Existe, ainda, restrição à realização de prova pericial complexa, além de o rito ser concentrado5 e só existir a possibilidade de se utilizar do Recurso Inominado6 ou dos Embargos de Declaração7. Nesse contexto, os incidentes processuais praticamente não são admitidos, com exceção da arguição de suspeição e impedimento do juiz, que são processadas em autos apartados e observado o rito do Código de Processo Civil. (TJ-RJ - MS: 0000079-47.2017.8.19.9000 RIO DE JANEIRO CAPITAL II JUI ESP CIV, Relator: ALEXANDRE CHINI NETO, Data de Julgamento: 20/06/2017, CAPITAL 4a. TURMA RECURSAL DOS JUI ESP CIVEIS, Data de Publicação: 22/06/2017) ${ }^{83}$.

Sendo assim, e em observância ao princípio da especialidade, o CPC/2015 somente terá aplicação ao Sistema dos Juizados Especiais nos casos de expressa e específica remissão ou na hipótese de compatibilidade com os critérios previstos no art. $2^{\circ}$ da Lei 9.099/95.

Nesse sentido, o Fórum Nacional de Juizados Especiais-FONAJE, através do Enunciado de n⿳0 161 , posicionou-se:

ENUNCIADO 161 - Considerado o princípio da especialidade, o CPC/2015 somente terá aplicação ao Sistema dos Juizados Especiais nos casos de expressa e específica remissão ou na hipótese de compatibilidade com os critérios previstos no art. $2^{\circ}$ da lei no 9.099/95 (XXXVIII Encontro - Belo Horizonte-MG) ${ }^{84}$.

\subsubsection{As tutelas de urgência antecipadas no procedimento dos Juizados Especiais Cíveis - Lei 9.099/95}

A Lei 9.099/95, que instituiu os Juizados Especiais Cíveis, é silente no que se refere ao cabimento de tutela de urgência antecipada no âmbito dos Juizados Especiais Cíveis, razão pela qual, faz-se necessário analisar a compatibilidade da referida tutela, prevista no novo Código de Processo Civil, observando o princípio da especialidade e os critérios principiológicos adotados pelo legislador na Lei dos Juizados Especiais Cíveis.

$\mathrm{O}$ novo $\mathrm{CPC}$, inovando a legislação atinente às tutelas antecipadas (satisfativas), estabelece no art. 294, que a tutela antecipada fundada na urgência pode ser requerida (concedida) em caráter incidental e antecedente.

\footnotetext{
${ }^{83}$ Disponível em: <https://tjrj.jusbrasil.com.br/jurisprudencia/471202554/mandado-de-segurancacpc-ms-794720178199000-rio-de-janeiro-capital-ii-jui-esp-civ>. Acesso em: 01 jul. 2017.

${ }^{84}$ Fórum Nacional de Juizados Especiais - FONAJE. Enunciado 161. Disponível em: <http://www.amb.com.br/fonaje/?p=32>. Acesso em: 03 jul. 2017.
} 


\section{Conforme lição de Fredie Didier Jr.:}

A tutela provisória incidental é aquela requerida dentro do processo em que se pede ou já se pediu a tutela definitiva, no intuito de adiantar seus efeitos. É requerimento contemporâneo ou posterior à formulação do pedido de tutela definitiva. A tutela provisória antecedente é aquela que deflagra o processo em que se pretende, no futuro, pedir a tutela definitiva. É requerimento anterior à formulação do pedido de tutela definitiva e tem por objetivo adiantar seus efeitos. Primeiro pede-se a tutela provisória, só depois, pede-se a tutela definitiva ${ }^{85}$.

O instituto da tutela antecipada foi inserido no ordenamento pátrio através da Lei $n^{\text {o }}$ : 8.952/94, que deu nova redação ao art. 273, CPC, possibilitando, assim, a obtenção de tutela sumária satisfativa no curso do processo de conhecimento, em caráter incidental.

A discussão quanto ao cabimento da tutela antecipada no âmbito dos Juizados Especiais Cíveis não é recente, sendo certo que abalizada Doutrina bem como a jurisprudência brasileira enfrentaram o tema durante um longo período.

Inegavelmente, a discussão quanto ao cabimento da tutela antecipada no âmbito dos Juizados Especiais Cíveis restringiu-se às tutelas antecipadas incidentais, haja vista a inexistência quanto à possibilidade de requerimento em caráter antecedente na legislação revogada.

Analisando o tema sob a égide do Código de Processo Civil de 1973, Humberto Theodoro Júnior asseverou:

(...) embora a lei n. 9099/95 seja omissa a respeito, é intuitivo que, nas lacunas das normas específicas do Juizado Especial, terão cabimento as regras do Código de Processo Civil, mesmo porque o art. art. 272, par. Único, contém previsão genérica de que suas normas gerais sobre procedimento comum aplicam-se complementarmente ao procedimento sumário e aos especiais. É de reconhecer-se que, entre outros, institutos como a repressão à litigância temerária, à antecipação de tutela e a medidas cautelares devem ser acolhidos no âmbito do Juizado Especial Civil, assim como todo o sistema normativo do Código de Processo Civil, em tudo que seja necessário para suprir as omissões da lei específica, desde que não interfira em suas disposições expressas e não atrite com seus princípios fundamentais. No entanto, é importante ressaltar que nenhuma lacuna da lei $\mathrm{n}$. 9099/95 poderá ser preenchida por regra do Código de Processo Civil que se mostre incompatível com os princípios que norteiam o Juizado Especial na sua

\footnotetext{
${ }^{85}$ DIDIER JR.; BRAGA; OLIVEIRA, 2015, p. 570-571.
} 
concepção constitucional e na sua estruturação normativa específica ${ }^{86}$. (Grifo nosso)

Fredie Didier Jr., também se posiciona no sentido de que a Tutela provisória é plenamente cabível nos procedimentos especiais, e que no caso de ausência de previsão própria para a concessão de tutela provisória de urgência (satisfativa) ou de evidência, se preenchidos os pressupostos genéricos dos arts. 303, 305 e 311, do Novo CPC, não há óbice para a concessão da Tutela requerida ${ }^{87}$.

Segundo a doutrina de Rodolfo Kronemberg Hartmann:

Quanto aos juizados estaduais (Lei $n^{\circ}$ 9.099/95), realmente não há previsão clara à respeito da concessão de tutelas de urgência mas, estando atento aos princípio norteadores do microssistema dos juizados (art. $2^{\circ}$, Lei $\mathrm{n}^{\circ}$ 9.099/95), que é expresso em mencionar os critérios da simplicidade, informalidade e celeridade processual, também é recomendável que se mantenha o mesmo modelo anterior, ou seja, tais decisões de cunho antecipatório poderão ser concedidas ou revogadas nos próprios autos e, havendo inconformismo, este deve ser manifestado pela via do mandado de segurança, em razão da ausência de disposição específica autorizando o uso de algum recurso. Com isso, o microssistema dos juizados permaneceria íntegro, possibilitando que aqueles processos de competência dos juizados estaduais também possam ter um modelo para a análise de tutelas de urgência muito semelhante ao dos demais ${ }^{88}$.

A jurisprudência manifesta-se, majoritariamente, pelo cabimento da tutela antecipada incidental no âmbito dos Juizados Especiais, com diversos precedentes nesse sentido, destacando-se:

EMENTA - JUIZADO ESPECIAL CÍVEL. DIREITO CONSUMIDOR. CUMPRIMENTO DE SENTENÇA. RECLAMAÇÃO. ANTECIPAÇÃO DOS EFEITOS DA TUTELA. DEFERIMENTO. DESCONSIDERAÇÃO DA PERSONALIDADE JURÍDICA. TEORIA MENOR DE ACORDO COM O PARÁGRAFO $5^{\circ}$, DO ART. 28 DO CDC. RECLAMAÇÃO CONHECIDA E PROVIDA. (TJ-DF - RCL: 07004553020158070000, Relator: ROBSON BARBOSA DE AZEVEDO, Data de Julgamento: 19/08/2015, TERCEIRA TURMA RECURSAL, Data de Publicação: Publicado no DJE : 10/09/2015 . Pág.: Sem Página Cadastrada.)

\footnotetext{
${ }^{86}$ THEODORO JR., Humberto. Curso de Direito Processual Civil. Procedimentos Especiais. $41^{\mathrm{a}}$ ed., v. III. Rio de Janeiro: Forense, 2009. p. 414.

${ }^{87}$ DIDIER JR.; BRAGA; OLIVEIRA, 2015, p. 576.

${ }^{88}$ HARTMANN, Rodolfo Kronemberg. Novo Código de Processo Civil - Comparado e Anotado. $1^{\mathrm{a}}$ ed. Niterói: Impetus, 2015. p. 262-263.
} 


\begin{abstract}
EMENTA: MANDADO DE SEGURANÇA - ANTECIPAÇÃO DA TUTELA POSSIBILIDADE NOS JUIZADOS ESPECIAIS CIIVEIS - DECISÃO QUE NÃO SE REVELA TERATOLÓGICA - DENEGAÇÃO DA ORDEM. A antecipação da tutela é cabível nos Juizados Especiais Cíveis, tratando-se de medida que se coaduna perfeitamente com os modernos princípios de celeridade da prestação jurisdicional com justa distribuição do ônus da demora processual entre as partes. São cabíveis a tutela acautelatória e a antecipatória em sede dos Juizados Especiais Cíveis, em caráter incidental. (II Encontro Nacional dos Coordenadores de Juizados Especiais, Cuiabá, dezembro de 1997) É compatível com o rito estabelecido pela Lei $n^{\circ}$ 9.099/95 a tutela antecipatória a que alude o art. 273 do Código de Processo Civil. (Enunciado nº 06, do 1o EMJERJ) Decisão que, em antecipação de tutela determinou o bloqueio da transferência de veículo perante o Detran em razão de garantia da satisfação de obrigação pelo Impetrante, é medida acautelatória facultada ao Juízo, que não se revela teratológica. Denegada a ordem. (TJPR. 2006.0003477-7. Rel. Jose Sebastião Fagundes Cunha. 28/07/2006). (grifo nosso)
\end{abstract}

De fato, analisando o instituto da tutela antecipada incidental previsto na atual legislação, constata-se que sua aplicabilidade no âmbito dos Juizados Especiais deve ser mantida, por manifesta ausência de confronto com os princípios norteadores constantes no art. $2^{\circ}$ da Lei 9.0999/95, atingindo, assim, a finalidade da prestação jurisdicional, com a observância da efetividade e celeridade no procedimento especial.

Em que pese a Doutrina majoritária, defender o cabimento da Tutela de urgência antecipada incidental no âmbito da Lei 9.099/95, bem como diversos precedentes judiciais apontarem o cabimento da medida, faz-se necessária uma análise cuidadosa, e detalhada, das mudanças no regime das tutelas antecipadas, advindas do Novo Código de Processo Civil, em especial quanto a possibilidade de requerimento em caráter antecedente.

Conforme visto anteriormente, a possibilidade e o procedimento para requerimento de antecipação dos efeitos da tutela em caráter antecedente são uma das grandes inovações trazidas pelo legislador no novo código de processo civil, Lei $13.105 / 2015$.

$\mathrm{O}$ art. 303, do novo CPC, estabelece as regras procedimentais da tutela antecipada antecedente, ocasião em que nos casos onde a urgência for contemporânea à propositura da ação, a parte pode limitar-se ao requerimento da tutela antecipada, indicando o pedido de tutela final, com a exposição da lide, do direito que se pretende buscar com a demonstração do perigo de dano ou do risco ao resultado útil do processo. 
Contudo, faz-se necessária a análise comparativa do procedimento estabelecido pelo novo CPC (art. 303 e 304) com a legislação atinente aos Juizados Especiais Cíveis (Lei. 9.099/95), para que, assim, delimite-se a possibilidade de adequação e compatibilidade.

O novo código de processo civil estabelece, no art. 304, que a tutela de urgência antecipada antecedente (art. 303, do CPC), concedida, torna-se estável se "da decisão que a conceder não for interposto o respectivo recurso", ocasião em que o processo será extinto ( $§ 1^{\circ}$, do art. 304 , do CPC).

Sendo assim, a estabilização da tutela antecedente ocorre a partir do momento em que o réu opta por ficar inerte quando intimado da decisão concessiva que antecipou os efeitos da tutela, ocasião em que a tutela conservará seus efeitos enquanto não for revista, reformada ou invalidada $\left(\S 3^{\circ}\right.$, do art. 304 , do CPC).

A estabilização prevista consiste na conservação dos efeitos da medida, ou seja, na ausência de manifestação posterior à decisão que concedeu a tutela antecipada, o processo ficará suspenso, entretanto, será mantida a eficácia dos efeitos da referida medida.

Por tratar-se de decisão interlocutória, conforme estabelece o art. 203, $\S 2^{\circ}$, do CPC, o recurso cabível para impugnar tal decisão é o Agravo de Instrumento, previsto no art. 1.015, I, do CPC, no prazo de 15 dias), que, afasta a possibilidade de estabilização da tutela antecedente.

Ocorre que a Lei $\mathrm{n}^{\text {o }} 9.099 / 95$ é silente quanto à possibilidade de interposição do Recurso de Agravo de Instrumento contra as decisões interlocutórias proferidas no Microssistema dos Juizados Especiais Cíveis, razão pela qual se faz necessário analisar a viabilidade do Recurso de Agravo de Instrumento no âmbito dos Juizados Especiais Cíveis, e sua consequente compatibilidade.

De fato, analisando a legislação dos Juizados Especiais Cíveis, verifica-se o cabimento, expresso, de apenas dois tipos de recursos contra as decisões proferidas no âmbito dos Juizados Especiais: o Recurso Inominado (art. 41) e os Embargos de Declaração (art. 48). Além desses recursos, por força do art. 102, III, 
da Constituição Federal Brasileira e da Súmula de nº 640, do STF, também é admissível a interposição de Recurso Extraordinário.

Constata-se, assim, no âmbito do microssistema dos juizados especiais, a ausência de previsão legal quanto à possibilidade de impugnação das decisões interlocutórias, razão pela qual se fala que o legislador adotou um dos consectários do princípio da oralidade, ou seja, a regra da "irrecorribilidade das decisões interlocutórias".

Conforme salienta Felippe Boring:

A razão dessa postura, por certo, foi evitar que a oralidade ficasse comprometida pela interposição de um recurso antes da prolação da sentença, vulnerando a concentração dos atos em audiência e a identidade física do juiz. Além disso, a fase cognitiva do procedimento sumaríssimo foi concebida para produzir uma sentença em, no máximo, 15 dias, tornando desnecessária qualquer revisão sobre as pouquíssimas decisões interlocutórias que eventualmente pudessem vir a ser proferidas $^{89}$.

A Lei $n^{\circ} 9.099 / 95$, por sua vez, não prevê a possibilidade de impugnação de decisões interlocutórias em primeiro grau de jurisdição, motivo pelo qual, não obstante o tema gere acirrada discussão doutrinária e jurisprudencial, prevalece o entendimento acerca de sua irrecorribilidade.

A limitação imposta pelo legislador quanto aos recursos cabíveis, demonstra o prestígio aos princípios da oralidade e simplicidade, previstos no art.

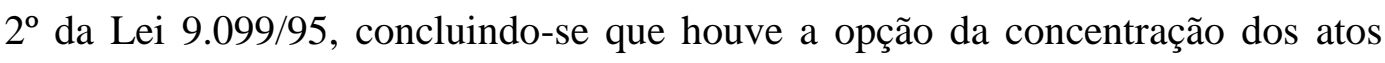
processuais.

Em razão da omissão quanto ao cabimento do Agravo de Instrumento nos Juizados Especiais, a doutrina passou a defender a existência do princípio da imprescritibilidade das decisões interlocutórias, ocasião em que os atos decisórios podem (devem) ser combatidos apenas no final do processo (da sentença), através de Recurso Inominado, inexistindo preclusão da matéria decidia, e não impugnada.

Nesse sentido, manifestou-se a $3^{\mathrm{a}}$ Turma Recursal do Tribunal do Rio Grande do Sul/RS:

\footnotetext{
${ }^{89}$ ROCHA, 2012, p. 229-230.
} 
RECURSO INOMINADO. DECISÃO QUE RECONHECE A ILEGITIMIDADE DA REQUERIDA SERASA. DECISÃO INTERLOCUTÓRIA. NÃO CONHECIMENTO DO RECURSO INOMINADO QUANDO MANEJADO EM FACE DE DECISÃO INTERLOCUTÓRIA, A QUAL, NA SISTEMÁTICA DO JUIZADO ESPECIAL CÍVIL, NÃO PRECLUI. IMPOSSIBILIDADE DE UTILIZAÇÃO DO RECURSO INOMINADO COMO SUCEDÂNEO DE AGRAVO DE INSTRUMENTO. INTELIGÊNCIA NO ART. 41 DA LEI N $N^{\circ}$ 9.099/95. RECURSO NÃO CONHECIDO $^{90}$.

Quanto à impossibilidade de manejo do Recurso de Agravo de Instrumento, a Primeira Turma do TJPR e a Primeira Turma do TJRS, decidiram, respectivamente:

AGRAVO DE INSTRUMENTO. IRRECORRIBILIDADE DE DECISÕES INTERLOCUTÓRIAS NO JUIZADO ESPECIAL. AUSÊNCIA DE PREVISÃO NA LEI No 9.099/95. AGRAVO DE INSTRUMENTO NÃO CONHECIDO.

1. (...) 2. A Lei $n^{\circ} 9.099 / 95$, destaca-se, não prevê o recurso de agravo de instrumento, não sendo aplicado, subsidiariamente o Código de Processo Civil. No procedimento diferenciado dos Juizados especiais, não prevê impugnação de decisão judicial através de agravo de instrumento. (...). A Lei $\mathrm{n}^{\circ}$ 9.099/95 não prevê a possibilidade de agravo de instrumento ou de aplicação de subsidiária do Código de Processo Civil para criar outras espécies de recursos não estabelecidos nos procedimentos dos Juizados Especiais. Por tal razão, não há preclusão de decisões e com fulcro no artigo 557, caput do Código de Processo Civil, aplicável ao sistema dos Juizados Especiais Cíveis (grifei) (TJPR 0001308-94.2015.8.16.900 - Rel.: Vivian Cristiane Eisenberg de Almeida Sobreiro - Julg. 24.08.2015). Ademais, destaca-se o disposto no Enunciado $n^{\circ}$ 15 do FONAJE, vedando, também, o cabimento do agravo de instrumento no âmbito dos Juizados Especiais: "Nos Juizados Especiais não é cabível o recurso de agravo, exceto nas hipóteses dos artigos 544 e 557 do CPC". Diante do exposto, não há que se falar na admissibilidade do recurso interposto. Dessa forma, com amparo no artigo 557 do Código de Processo Civil, não conheço do Agravo de instrumento, conforme fundamentação acima exposta, e nego-lhe seguimento, tendo em vista que é manifestamente inadmissível. Intimem-se. Oportunamente, arquive-se. Curitiba, 07 de outubro de 2015, Aldemar Sternadt, Juiz Relator ${ }^{91}$.

AGRAVO DE INSTRUMENTO. DECISÃO INTERLOCUTÓRIA. ADIAMENTO DA AUDIÊNCIA. SUSPENSÃO DO FEITO ATÉ ESGOTAMENTO DA PRETENSÃO ATRAVÉS DO PROGRAMA SOLUÇÃO DIRETA CONSUMIDOR. INCONFORMISMO DO AGRAVANTE.

\footnotetext{
90 TJ-RS. Recurso Cível No 71004399093. Terceira Turma Recursal Cível. Turmas Recursais. Min. Rel.: Carlos Eduardo Richinitti, Julgado em: 27 jun. 2013.

91 TJ-PR. Agravo de Instrumento no. 20150000121-3. Primeira Turma Recursal. Terra Roxa. Min. Rel.: Aldemar Sternadt. Julgado em: 17 dez. 2015.
} 
RECURSO SEM PREVISÃO LEGAL NO AMBITO DO SISTEMA DOS JUIZADOS ESPECIAIS CÍVEIS. IRRECORRIBILIDADE DAS DECISÕES INTERLOCUTÓRIAS. O manejo de agravo de instrumento contra as decisões interlocutórias proferidas pelos julgadores a quo não encontra respaldo na legislação que rege o Juizado Especial Cível. Inconformismo que não merece conhecimento. RECURSO NÃO CONHECIDO. (Agravo de Instrumento $\mathrm{N}^{\circ}$ 71005811823, Primeira Turma Recursal Cível, Turmas Recursais, Relator: José Ricardo de Bem Sanhudo, Julgado em 13/11/2015) ${ }^{92}$.

Impossibilitar o manejo de Agravo de Instrumento para impugnar a concessão de tutela antecipada antecedente é, de fato, afastar a possibilidade de estabilização dos seus efeitos, idealizada pelo legislador como técnica monitória, esvaziando-se, assim, o instituto da tutela antecipada antecedente quando aplicado na Lei 9.099/95.

Com isso, e diante da impossibilidade de utilização do Recurso de Agravo de Instrumento para impugnar a decisão concessiva de tutela antecipada antecedente, verifica-se a inviabilização, e, a consequente, incompatibilidade da estabilização da tutela antecedente no âmbito dos Juizados Especiais Cíveis.

Além disso, de acordo com o procedimento da tutela antecipada requerida em caráter antecedente, estabilizada a tutela, o art. $304 \S 2^{\circ}$, do novo CPC, autoriza que qualquer uma das partes poderá demandar a outra com o intuito de rever, reformar ou invalidar a tutela antecipada concedida.

Marinoni ressalta que:

Como é óbvio, se a tutela do direito é insuficiente ao autor, ele não fica impedido de propor ação para pleitear uma ou outra forma de tutela (v.g. inibitória quando antes pedida remoção do ilícito), outro modo de prestação da tutela (v. g.) paralisação de atividades quando antes requerida instalação de filtro) ou a própria tutela de direito em maior extensão (v. g. ressarcitória na forma específica quando antes pedida ressarcitória pelo equivalente, ou seja, antecipação de soma)... Ora, se a decisão que concede a tutela que se estabiliza não produz coisa julgada, o autor fica livre para pedir outro modo de prestação da tutela ou tutela que vá além da estabilizada ${ }^{93}$.

Neste caso, qualquer uma das partes tem legitimidade para propor ação para discutir a tutela estabilizada, no prazo de dois anos contados da ciência da

92 TJ-RS. Agravo de Instrumento no. 71005811823. Primeira Turma Recursal Cível. Min. Rel.: José Ricardo de Bem Sanhudo. Julgado em: 13 nov. 2015. Data de Publicação: Diário da Justiça 17 nov. 2015.

${ }^{93}$ MARINONI, 2017, p. 240. 
decisão que extinguiu o processo (art. $304, \S 5^{\circ}$, do CPC), com o intuito de rever, reformar ou invalidar a tutela estabilizada.

A competência funcional dessa ação será a do juízo que analisou o processo que deu origem à estabilização, conforme estabelece o art. 304, $\S 4^{\circ}$, do CPC, "prevento o juízo em que a tutela antecipada foi concedida", podendo a parte requerer o desarquivamento dos autos para a obtenção de elementos capazes de instruir a petição inicial da ação.

Importante ressaltar que a Lei 9.099/95, conforme seu art. $8^{\circ}$, caput e $\S 1^{\circ}$, limita o número de pessoas que tem legitimidade para propositura de ações perante os Juizados Especiais, criando verdadeiro rol taxativo, que estabelece:

Art. $8^{\circ}$ Não poderão ser partes, no processo instituído por esta Lei, o incapaz, o preso, as pessoas jurídicas de direito público, as empresas públicas da União, a massa falida e o insolvente civil.

$\S 1^{\circ}$ Somente serão admitidas a propor ação perante o Juizado Especial: (Redação dada pela Lei ${ }^{\circ} 12.126$, de 2009)

I - as pessoas físicas capazes, excluídos os cessionários de direito de pessoas jurídicas; (Incluído pela Lei nº 12.126, de 2009)

II - as pessoas enquadradas como microempreendedores individuais, microempresas e empresas de pequeno porte na forma da Lei Complementar $\mathrm{n}^{\mathrm{o}}$ 123, de 14 de dezembro de 2006; (Redação dada pela Lei Complementar $\mathrm{n}^{\circ}$ 147, de 2014)

III - as pessoas jurídicas qualificadas como Organização da Sociedade Civil de Interesse Público, nos termos da Lei no 9.790, de 23 de março de 1999; (Incluído pela Lei $\mathrm{n}^{\circ} 12.126$, de 2009)

IV - as sociedades de crédito ao microempreendedor, nos termos do art. $1^{\circ}$ da Lei $\mathrm{n}^{\mathrm{o}} 10.194$, de 14 de fevereiro de 2001. (Incluído pela Lei $\mathrm{n}^{\circ} 12.126$, de 2009)"

\section{Conforme aponta Alexandre Martins Flexa:}

Dessa forma, aquelas pessoas jurídicas que não estão elencadas no rol do art. $8^{\circ}$, da Lei de regência, ou seja, a maioria dos réus hoje demandados perante os Juizados Especiais Cíveis (Banco, Concessionárias de Serviços Públicos, 
Empresas de Seguro, Hospitais e etc.), ficariam impossibilitadas de propor ação revocatória para atacar os efeitos da tutela perante o mesmo Juizado Cível em que se desenvolveu o processo no qual fora deferida a tutela antecipada que se estabilizou ${ }^{94}$.

Com razão, impossibilitar a parte que sofreu a medida antecipatória de ajuizar ação revocatória, nos termos do art. $304, \S \S 4^{\circ}$ e $5^{\circ}$, sob o argumento de ilegitimidade processual ativa no âmbito dos Juizados Especiais, viola o direito da parte ao devido processo legal, à igualdade e efetividade prevista no ordenamento jurídico brasileiro, caracterizando-se, assim, uma incompatibilidade flagrante das tutelas antecipadas antecedentes quando aplicadas aos Juizados Especiais.

Nessa perspectiva, o Tribunal de Justiça do Estado do Rio de Janeiro aprovou o Enunciado de nº 18/2016, no XI Encontro de Juízes Especiais Cíveis e Turmas Recursais, que assentou:

Enunciado $\mathrm{n}^{\mathrm{o}}$ 18.2016: TUTELA DE URGÊNCIA EM CARÁTER ANTECEDENTE - VEDAÇÃO. Os procedimentos de tutela de urgência requeridos em caráter antecedente, na forma prevista nos artigos 303 a 310 do CPC/2015, são incompatíveis com o Sistema dos Juizados Especiais.

O FONAJE - Fórum Nacional de Juizados Especiais caminhou no mesmo sentido:

ENUNCIADO 163 - Os procedimentos de tutela de urgência requeridos em caráter antecedente, na forma prevista nos arts. 303 a 310 do CPC/2015, são incompatíveis com o Sistema dos Juizados Especiais (XXXVIII Encontro - Belo Horizonte - MG).

O Tribunal de Justiça de São Paulo indeferiu, recentemente, um requerimento de tutela antecipada antecedente no Juizado Especial Cível, acolhendo a orientação dos Enunciados supramencionados:

$1^{\text {a }}$ Vara do Juizado Especial Cível - Foro Regional IV - Lapa

\footnotetext{
${ }^{94}$ FLEXA, Alexandre; CHINI, Alexandre. A tutela de urgência em caráter antecedente no sistema dos Juizados Especiais cíveis estaduais. Disponível em: <http://www.migalhas.com.br/dePeso/16,MI240313,31047-

A+tutela+de+urgencia+em+carater+antecedente+no+sistema+dos+Juizados>. Acesso em: 6 jul. 2017.
} 
PROCESSO Nº 1003505-14.2016.8.26.0004

TUTELA ANTECIPADA ANTECEDENTE - JUIZADO INCOMPATIBILIDADE -“Com o advento do Novo Código de Processo Civil, a tutela de urgência do artigo 300, possui procedimentos dispostos nos artigos 303 e 304, ritos estes que não se que se coadunam com o procedimento especial dos Juizados Especiais. Neste sentido, decidiu o XXXVIII Fojesp, ao editar o Enunciado 68. Esta também foi a orientação adotada no último Fonaje, segundo o Enunciado 163, que assim dispõe: "Os procedimentos de tutela de urgência requeridos em caráter antecedente, na forma prevista nos artigos 303 a 310 do CPC/2015, são incompatíveis com o Sistema dos Juizados Especiais." Portanto, indefiro o pedido de tutela de urgência requerida. Cite-se a parte requerida, no prazo de 15 dias CORRIDOS (conforme Comunicado 380/16 do TJSP e CGJ e Enunciado 74 do XXXVIII FONAJE) para apresentar contestação, podendo ser dispensada a audiência de conciliação e a de instrução, considerando a matéria de direito envolvida, aplicando-se o julgamento antecipado da lide. Int." (Processo $\mathrm{n}^{\mathrm{o}}$ 1003505-14.2016.8.26.0004 - $1^{\mathrm{a}}$ Vara do Juizado Especial Cível - Foro Regional IV - Lapa - TJSP) ${ }^{95}$.

\footnotetext{
${ }^{95}$ Disponível em: $<$ https://esaj.tjsp.jus.br/cpopg/show.do?processo.codigo=040013XAP0000\&processo.foro=4\&uui dCaptcha=sajcaptcha_0fa14512846f4957bc671ca16f5f10a9>. Acesso em: 8 jul. 2017.
} 


\section{CONCLUSÃO}

O sistema jurídico brasileiro busca, incessantemente, a evolução legislativa para uma rápida e efetiva entrega da prestação jurisdicional. Para consecução desses objetivos foram criados diversos institutos e instrumentos a fim de responder de forma célere e eficiente as demandas judiciais, solucionando, assim, os conflitos existentes.

Entre os institutos criados elencam-se a tutela provisória de urgência antecipada e os juizados especiais, ambos como remédio para uma justiça mais célere e efetiva.

Os Juizados Especiais Cíveis, criados através da Lei 9.099/95, surgiram no ordenamento jurídico brasileiro objetivando atender as camadas mais vulneráveis da população, garantindo o acesso à justiça nas causas de menor complexidade e de pequeno valor, visando maior efetividade da justiça, mediante processo simplificado, informal, menos oneroso, célere e tempestivo, fundado em princípios de natureza, eminentemente, procedimental.

Diante disso, independente de regras que prescrevam a aplicabilidade de outros institutos no procedimento dos Juizados Especiais Cíveis (não previstos na Lei 9.099/95), deve-se verificar a sua compatibilidade analisando a sistemática principiológica adotada pelo legislador, ocasião em que, verificada a incompatibilidade a regra deve ser afastada.

Nesse contexto, a tutela de urgência antecipada prevista no novo CPC, deve ser aplicada nos Juizados Especiais somente nas ocasiões em que o seu procedimento se adequem, observando a regra hermenêutica da especialidade e também da compatibilidade teleológica, preservando-se, assim, a autonomia dos Juizados Especiais para regular o seu procedimento.

Com isso, analisadas as tutelas antecipadas (incidentais e antecedentes) previstas no novo CPC, entende-se que a tutela de urgência antecipada antecedente (artigos 294 e $\S$ único, 303 e 304) é incompatível com os critérios previstos no art. $2^{\circ}$, da Lei 9.099/95, e com o procedimento adotado pelos Juizados Especiais Cíveis (Lei nº 9.099/95). 


\section{REFERÊNCIAS BIBLIOGRÁFICAS}

BRASIL. Constituição Federal (1988). Art. 5. Inciso LXXVIII. A todos, no âmbito judicial e administrativo, são assegurados a razoável duração do processo e os meios que garantam a celeridade de sua tramitação. (Incluído pela Emenda Constitucional $n^{\circ} 45$, de 2004). Disponível em:

$<$ http://www.planalto.gov.br/ccivil_03/constituicao/constituicao.htm>. Acesso em: 5 mai. 2017.

BRASIL. Constituição Federal (1988). Art. 5. XXXV: XXXV. A lei não excluirá da apreciação do Poder Judiciário lesão ou ameaça a direito. Disponível em:

<http://www.planalto.gov.br/ccivil_03/constituicao/constituicao.htm>. Acesso em: 5 mai. 2017.

BRASIL. Lei $\mathrm{n}^{\circ}$ 13.105, de 16 de março de 2015. Código Civil. Disponível em: <http://www.planalto.gov.br/ccivil_03/_ato2015-2018/2015/lei/113105.htm>. Acesso em: 5 mai. 2017.

BRASIL. Presidência da República. Decreto no 678, de 6 de novembro de 1992. Promulga a Convenção Americana sobre Direitos Humanos (Pacto de São José da Costa Rica), de 22 de novembro de 1969. Disponível em: <http://www.planalto.gov.br/ccivil_03/decreto/d0678.htm>. Acesso em: 7 mai. 2017.

BRASIL. Presidência da República. Lei no 9.099, de 26 de setembro de 1995. Dispõe sobre os Juizados Especiais Cíveis e Criminais e dá outras providências. Disponível em: <http://www.planalto.gov.br/ccivil_03/leis/L9099.htm>.

Acesso em: 30 jun. 2017.

BUENO, Cassio Scarpinella. Curso Sistematizado de Direito Processual Civil: Teoria Geral do Direito Processual Civil. v. 1. $8^{\mathrm{a}}$ ed. rev. e atual. São Paulo: Saraiva, 2014.

Curso Sistematizado de Direito Processual Civil - Procedimentos do Código de Processo Civil, Juizados Especiais. $3^{\mathrm{a}}$ ed. $2^{\mathrm{a}}$ tiragem. T. II, 2014.

CÂMARA, Alexandre Freitas. Lições de Direito Processual Civil. v. 1. $25^{\mathrm{a}}$ ed. São Paulo: Atlas, 2014.

DIDIER JR., Fredie. Curso de direito processual civil. Parte geral. Processo de conhecimento. $17^{\mathrm{a}}$ ed. v. 1. Salvador: Ed. Juspodivm, 2015.

; BRAGA, Paula Sarno; OLIVEIRA, Rafael Alexandria de. Curso de Direito Processual Civil: Teoria da Prova, direito probatório, ações probatórias, 
decisão, precedente, coisa julgada e antecipação dos efeitos da tutela. $10^{\mathrm{a}}$ ed. Salvador: Ed. Juspodivm, 2015.

Disponível em: <https://tjrj.jusbrasil.com.br/jurisprudencia/471202554/mandadode-seguranca-cpc-ms-794720178199000-rio-de-janeiro-capital-ii-jui-esp-civ > . Acesso em: 3 jul. 2017.

Disponível em:

$<$ https://esaj.tjsp.jus.br/cpopg/show.do?processo.codigo=040013XAP0000\&proce sso.foro=4\&uuidCaptcha=sajcaptcha_0fa14512846f4957bc671ca16f5f10a9> .

Acesso em: 8 jul. 2017.

DONIZETTI, Elpídio. A corte dos homens pobres e a principiologia do CPC/2015: $O$ que serve ou não aos Juizados Especiais? In: Coleção Repercussões do Novo CPC. v. 7. Editora Juspodium, 2015.

FLEXA, Alexandre; CHINI, Alexandre. A tutela de urgência em caráter antecedente no sistema dos Juizados Especiais cíveis estaduais. Disponível em: <http://www.migalhas.com.br/dePeso/16,MI240313,31047-

A+tutela+de+urgencia+em+carater+antecedente+no+sistema+dos+Juizados $>$. Acesso em: 6 jul. 2017.

FRIEDE, Reis. 1949, Tutela antecipada, tutela específica e tutela cautelar: à luz da denominada Reforma do Código de Processo Civil. 6 ${ }^{a}$ ed. Rev., atual. e ampliada de acordo com a Lei $\mathrm{n}^{\circ} 10.444$, de 7 de maio de 2002. Rio de Janeiro: Forense, 2002.

GAJARDONI, Fernando da Fonseca. Os reflexos do tempo no processo Civil. Uma breve análise da qualidade do processo civil e europeu. Disponível em: $<$ http://myrtus.uspnet.usp.br/pesqfdrp/portal/professores/fernando/pdf/reflexos.pdf >. Acesso em: 5 mai. 2017.

HARTMANN, Rodolfo Kronemberg. Novo Código de Processo Civil Comparado e Anotado. $1^{\mathrm{a}}$ ed. Niterói: Impetus, 2015.

MARINONI, Luiz Guilherme. Tutela de Urgência e Evidência. $1^{\mathrm{a}}$ ed. São Paulo: Editora Revista dos Tribunais, 2017.

MENDONÇA, Delasmar et al.. Tutela Diferenciada. $6^{\text {a }}$ ed. Curitiba: IESDE Brasil S.A., 2011.

MITIDIERO, Daniel. Antecipação da tutela: da tutela cautelar à técnica antecipatória. $2^{\mathrm{a}}$ ed. Rev., ampl. e atual. São Paulo: Editora Revista dos Tribunais, 2014. 
PELEJA JUNIOR, Antonio Veloso; OLIVEIRA, Humberto Santarosa de. $O$ procedimento dos juizados especiais cíveis na perspectiva principiológica do Novo Código de Processo Civil: contraditório e motivação das decisões como alicerces do devido processo legal In: Coleção Repercussões do Novo CPC. v. 7. Editora Juspodium, 2015.

RIBEIRO, Leonardo Ferres da Silva, Tutela provisória: tutela de urgência e de evidência. $2^{a}$ ed. rev. In: ALVIM, Teresa Arruda; TALAMINI, Eduardo (Coord.). Coleção Liebman. São Paulo: Editora Revista dos Tribunais, 2016.

ROCHA, Felipe Borring. Manual dos Juizados Especiais Cíveis Estaduais: Teoria e Prática. $6^{\text {a }}$ ed. São Paulo: Atlas, 2012.

THEODORO JR., Humberto. Curso de Direito Processual Civil. Procedimentos Especiais. $41^{\text {a }}$ ed., v. III. Rio de Janeiro: Forense, 2009.

TJ-PR. Agravo de Instrumento no. 20150000121-3. Primeira Turma Recursal. Terra Roxa. Min. Rel.: Aldemar Sternadt. Julgado em: 17 dez. 2015.

TJ-RS. Agravo de Instrumento no. 71005811823. Primeira Turma Recursal Cível. Min. Rel.: José Ricardo de Bem Sanhudo. Julgado em: 13 nov. 2015. Data de Publicação: Diário da Justiça 17 nov. 2015.

TJ-RS. Recurso Cível No 71004399093. Terceira Turma Recursal Cível, Turmas Recursais, Min. Rel.: Carlos Eduardo Richinitti, Julgado em: 27 jun. 2013.

WAMBIER, Luiz Rodrigues. TALAMINI, Eduardo. $16^{\mathrm{a}}$ ed. Reformulada $e$ Ampliada de Acordo Com o Novo CPC. São Paulo: Editora Revista dos Tribunais, 2016.

; Curso Avançado de processo civil. processo comum de conhecimento e tutela provisória. 16 ${ }^{\mathrm{a}}$ ed. Editora Revista dos Tribunais, 2016. 